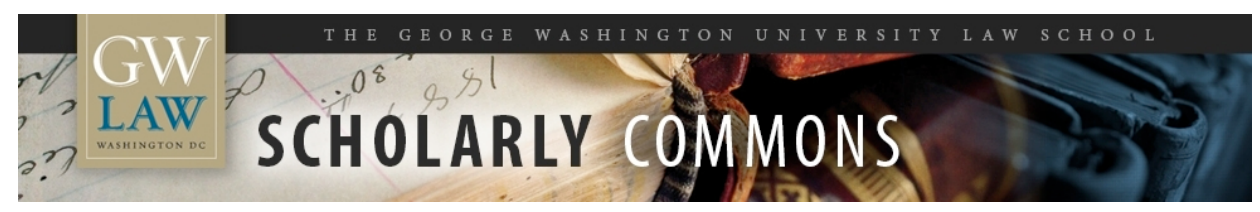

GW Law Faculty Publications \& Other Works

Faculty Scholarship

2018

\title{
Revisiting Revocation upon Divorce?
}

Naomi R. Cahn

George Washington University Law School, ncahn@law.gwu.edu

Follow this and additional works at: https://scholarship.law.gwu.edu/faculty_publications

Part of the Law Commons

\section{Recommended Citation}

Cahn, Naomi, Revisiting Revocation upon Divorce? (2018). Naomi R. Cahn, Revisiting Revocation upon Divorce?, 103 lowa L. Rev. 1879 (2018).; GWU Law School Public Law Research Paper No. 2018-39; GWU Legal Studies Research Paper No. 2018-39. Available at SSRN: https://ssrn.com/abstract=3248755

This Article is brought to you for free and open access by the Faculty Scholarship at Scholarly Commons. It has been accepted for inclusion in GW Law Faculty Publications \& Other Works by an authorized administrator of Scholarly Commons. For more information, please contact spagel@law.gwu.edu. 


\title{
Revisiting Revocation upon Divorce?
}

\author{
Naomi R. Cahn*
}

\begin{abstract}
In an increasing number of states, divorce presumptively renders an ex-spouse ineligible to benefit from the testator's will. Divorce may also impact other revocable dispositions in favor of the ex-spouse and exclude the ex-spouse's family members from benefitting in any way from the decedent's death. Revocation upon divorce statutes have became more common as divorce itself has become more common, and courts have been quite rigorous in interpreting the statutes, creating an almost irrevocable presumption of revocation. By contrast, other countries vary in their approaches to the effect of a divorce on testamentary and nonprobate transfers to an ex-spouse and family members.
\end{abstract}

This Article challenges the utility of the presumption of revocation upon divorce. In raising questions about the appropriateness of the presumption, this Article traces developments in divorce law-from the purely fault system to the no-fault system to contemporary, and more collaborative, approaches to divorce-to show the historical shifts towards contemporary attempts to dissolve the acrimony often associated with divorce. This Article also explores the relatively limited sociological and empirical material on actual individuals' preferences for disposition of their estates to ex-spouses and their families. And it examines the class, gender, and race aspects of wealth ownership as part of an effort to determine who is most likely to have probate and nonprobate assets affected by the revocation statutes. Finally, this Article discusses alternative approaches for states to consider.

I. INTRODUCTION 1880

II. ReVOCATION UpON Divorce Statutes IN THE UNITED STATES 1882

A. THE DEVELOPMENT OF REVOCATION UPON DIVORCE STATUTES 1883

* Harold H. Greene Professor, The George Washington University Law School. Thanks to Susan Gary, Adam Hirsch, Paula Monopoli, and Allison Tait for their comments, to Tom Gallanis for his support of this project, and to Ashley Carter, Mary Kate Hunter, and Mohammad Zaheerudin for their research assistance. 
B. PRESUMPTIONS OF REVOCATION-UPON-DIVORCE STATUTES 1888

C. HOW COURTS APPLY REVOCATION-UPON-DIVORCE STATUTES. 1889

D. REBUTTING THE PRESUMPTION 1891

III. Policy: Collaborative Divorce, Gender, AND Class.......... 1892

A. DIVORCE PROCESS CHANGES........................................ 1893

B. RELATIONSHIPS BETWEEN EX-FAMILY MEMBERS................... 1895

C. AdDITIONAL POLICY ISSUES: GENDER, CLASS, AND RACE ........ 1898

1. Gender ........................................................... 1898

2. Class ............................................................ 1900

3. Race .............................................................. 1902

IV. APPROACHES OF OTHER COUNTRIES.................................... 1909

V. MOVING FORWARD .............................................................. 1906

A. THE PRESUMPTION ITSELF ............................................ 1907

1. Abolishing the Presumption ................................ 1907

2. Making the Presumption Irrevocable ..................... 1908

3. Rebutting the Current Presumption....................... 1908

i. $\quad$ Reinterpreting Existing Language .......................... 1909

ii. Additional Language ......................................... 1910

a. Showing Probable Intent ......................... 1910

b. Guardianship of a Child ............................ 1911

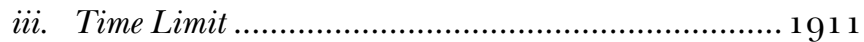

B. Statutory Changes OUtSide OF PRobate LAW.................. 1912

1. The Relationship Axis............................................ 1912

2. Estate Planners Beware ......................................... 1913

VI. CONCLUSION ............................................................. 1914

"The issue is not whether someone would probably want to revise a will following a consequential event, but whether someone who has not done so would probably want to do so. And that, on reflection, is a separate question."

\section{INTRODUCTION}

The presumption in an increasing number of states is that divorce renders an ex-spouse ineligible to benefit from the testator's will. The Uniform Probate Code ("UPC") and some states extend this ineligibility to

1. Adam J. Hirsch, Text and Time: A Theory of Testamentary Obsolescence, 86 WASH. U. L. REV. 609,633 (2009). 
other revocable dispositions in favor of the ex-spouse and also exclude the exspouse's family members from benefitting in any way. ${ }^{2}$ By contrast, other countries vary in their approaches to the effect of a divorce on testamentary and nonprobate transfers to an ex-spouse and family members. 3

Many commentators take the position that the (almost irrebuttable) presumption of revocation leads to the most appropriate outcome, 4 because it serves as a desirable rule of construction by effectuating the decedent's intent and increases efficiency by decreasing transaction costs associated with probate. 5 This Article challenges the utility of the presumption of revocation in the United States first, by comparing and contrasting that approach within different states and in other countries, then, by putting the presumption into both historical and sociological context, and finally, by analyzing the diverging approaches to the relational impact of divorce within family law and probate law.

In raising questions about the appropriateness of the presumption, the Article bridges the fields of both trust and estates law and family law, demonstrating their interrelationship and the consequent need for the two

2. See Unif. Probate Code $\$$ 2-8o4 (UNIF. LAW Comm'n, amended 2O10); Restatement (ThIRD) OF Prop.: Wills AND OTHER DONATIVE TRANSFERS § 4.1 (AM. LAW InST. 1999). The UPC presumption of revocation upon divorce can be rebutted in limited circumstances, "by the express terms of a governing instrument, a court order, or a contract relating to the division of the marital estate made between the divorced individuals before or after the marriage." UNIF. PROBATE CODE $\$ 2-804(\mathrm{~b})$. For commentary on this trend and federal-state preemption issues, see, e.g., T.P. Gallanis, ERISA and the Law of Succession, 65 OHIO ST. L.J. 185, 188-89 (2004); Susan N. Gary, Applying Revocation-on-Divorce Statutes to Will Substitutes, 18 QUINNIPIAC PROB. L.J. 83, 113 (2004); Laura A. Rosenbury, Federal Visions of Private Family Support, 67 VAND. L. REV. $1835,185^{\mathrm{O}-5^{2}}(2014)$.

3. For example, several Australian jurisdictions provide that a will is revoked by divorce or annulment; another revokes the will entirely; while in others, there is no revocation. See J. Neville Turner, Australia, in 1 INT'L ENCYClOPAEDIA OF LAWS FAMILY \& SUCCESSION LAW $219-20$ (R. Blanpain et al. eds., 2O14); LAW REFORM COMM. OF S. AUSTL., FORTY-FOURTH REPORT OF THE LAW REFORM COMMITTEE OF SOUTH AUSTRALIA TO THE ATTORNEY-GENERAL: RELATING TO THE EFFECT OF DIVORCE UPON WILLS 7-8 (1977), https://law.adelaide.edu.au/research/law-reforminstitute/documents / committee-reports/44-Effect-of-Divorce-upon-Wills.pdf.

4. See, e.g., E. Gary Spitko, The Expressive Function of Succession Law and the Merits of NonMarital Inclusion, 41 ARIZ. L. REV. 1063,1084 (1999) (observing that such provisions express an approach that "the property owner is unlikely to wish to benefit her former spouse and, had she thought about it, probably would have revoked the pre-divorce beneficiary designation"); Robert Whitman, Revocation and Revival: An Analysis of the I99o Revision of the Uniform Probate Code and Suggestions for the Future, 55 ALB. L. REV. 1035, 1054 (1992); Molly Brimmer, Comment, When an Ex Can Take It All: The Effect-and Non-Effect—of Revocation on a Will Post-Divorce, 74 MD. L. REV. 969, 971 (2015). As Adam Hirsch explains, the revocation upon divorce "inferences may be related to the presumption against absurd or unreasonable testamentary intentions . . . although they may also reflect the independent public policy of protecting the family." Adam J. Hirsch, Inheritance and Inconsistency, 57 OHIO ST. L.J. 1057, $1125^{-26}$ n.208 (1996) (citations omitted). As discussed, there is little empirical evidence for (or against) the presumption. See infra Section II.

5. Rules of construction serve as a proxy for what the drafter believes would be the decedent's intent. See Stewart E. Sterk \& Melanie B. Leslie, Accidental Inheritance: Retirement Accounts and the Hidden Law of Succession, 89 N.Y.U. L. Rev. 165, 214 (2014). 
areas of law to build on each other. Though the cores of both fields-family relationships and wealth transmission-differ and while their goals can conflict, ${ }^{6}$ they overlap in numerous places. This Article seeks to address one core overlap: the impact of family dissolution.

Part II of this Article explains the development and current status of the divorce-revocation presumption in the United States. For example, nineteenth century courts might find that divorce did not revoke a will 7 - or that it did. ${ }^{8}$ Part III turns to the family law, social, and economic contexts for revocation upon divorce statutes. It traces developments in divorce law-from the purely fault system to the no-fault system to contemporary, and more collaborative, approaches to divorce-to show the historical shifts in attempts to dissolve the acrimony often associated with divorce. ${ }^{9}$ Part III also explores the relatively limited sociological and empirical material on actual individuals' preferences for disposition of their estates to ex-spouses and their families. Lastly, Part III examines the class, gender, and race aspects of wealth ownership as part of an effort to determine who is most likely to have probate and nonprobate assets affected by the revocation statutes. Next, Part IV explores the varying approaches, both contemporary and historical, of other countries to reveal a lack of unity on the issue. ${ }^{10}$ Finally, Part V discusses alternative approaches for states to consider.

\section{REVOCATION UPON Divorce STATUTES IN THE UNITED STATES}

Changes in family status, such as marriage or the birth of a child, have historically served to change an individual's estate plan. Revocation upon divorce statutes became more common as divorce itself became more common, and courts have been quite rigorous in interpreting the statutes, creating an almost irrevocable presumption of revocation.

6. See, e.g., Naomi R. Cahn, Parenthood, Genes, and Gametes: The Family Law and Trusts and Estates Perspectives, 32 U. MEM. L. REv. 563, 564-65 (2002); Paula A. Monopoli, Nonmarital Children and Post-Death Parentage: A Different Path for Inheritance Law?, 48 SANTA CLARA L. REV. 857, 858-59 (2008); Allison Tait, Trusting Marriage (2018) (unpublished manuscript) (on file with author).

7. E.g., Charlton v. Miller, 27 Ohio St. 298, 304-05 (1875).

8. E.g., Lansing v. Haynes, 54 N.W. 699, 701 (Mich. 1893); Alan S. Wilmit, Note, Applying the Doctrine of Revocation by Divorce to Life Insurance Policies, 73 CORNELL L. REV. $6_{53}, 6_{5}{ }^{6-5} 5^{8}$ (1988).

9. E.g., Jane C. Murphy \& Jana B. Singer, Divorced From Reality: Rethinking Family DisPute RESOlUtion 1-3 (2015); Wendy PARIS, SPlitOPIA: DisPATCHES FROM TODAY's GOOD DIVORCE AND HOW TO PART WELL 2-12 (2016).

10. The British Inheritance (Provisions for Family and Dependents) Act 1975 permitted the decedent's ex-spouse who had not yet remarried to make a claim for financial provision against the decedent's estate. Ralph C. Brashier, Disinheritance and the Modern Family, 45 CASE WESTERN RES. L. REV. 83, 123-24 (1994). 


\section{A. THE DEVELOPMENT OF REVOCATION UPON DIVORCE STATUTES}

At common law, marriage served to revoke a woman's premarital will, while marriage and the birth of children revoked a man's. ${ }^{11}$ Subsequently, the laws in many American states evolved so that changes in the testator's circumstances, interpreted by courts to include either marriage or divorce, revoked an earlier will. ${ }^{12}$ Thus, for example, in 1962, Maine's Supreme Court interpreted the state will revocation statute-which provided for "revo[cation] by operation of law from subsequent changes in the condition and circumstances of the maker"-to revoke a pre-divorce will where there had been a property settlement. ${ }^{13}$ In the absence of a property settlement, however, courts at that time were generally unlikely to revoke a pre-divorce will. ${ }^{14}$ With respect to nonprobate assets, early courts consistently applied a gendered-based analysis: "the majority rule [was] that a decree of divorce in no way affects the rights of the divorced wife as a beneficiary in a husband's life insurance policy." ${ }^{15}$

Just as the no-fault divorce revolution sought to reform the divorce process and help the parties achieve a clean break with less acrimony, the 1969 UPC similarly sought to effectuate a clean break in divorcing spouses' estate plans. The 1969 UPC provided that any type of marital agreement (including a separation agreement) in which a spouse waived "all rights" in

11. Whitman, supra note 4 , at 1053 .

12. Id. at 1053 n.126 ("If, after the making of a will, the testator marries or is divorced or his marriage is annulled or dissolved or a child is born to the testator ... such marriage, divorce, annulment, dissolution, birth or adoption of a minor child shall operate as a revocation of such will ...." (alterations in original) (quoting CONN GEN. STAT. ANN. § 45a-257(a) (West Supp. 1992))).

13. Caswell v. Kent, 186 A.2d 581, $5^{81}$ (Me. 1962) (emphasis omitted) (quoting ME. R.S. 1954, ch. 169, § 3 (current version at ME. REV. STAT. ANN. tit. 18-A, § 2-5o8 (2017)).

14. Id. at 581-82; see Cases Noted, Divorce and Property Settlement as Implied Revocation of Prior Will, $5^{\circ}$ Colum. L. REV. 531, $53^{2}$ (1950) ("Except in the five states where statutes provide otherwise, it has been uniformly held that a testator's divorce does not, without more, operate as an implied revocation of a prior will.”); W.A. Graunke \& J.H. Beuscher, The Doctrine of Implied Revocation of Wills by Reason of Change in Domestic Relations of the Testator, 5 WIS. L. REV. $387,4^{10}$ (1930); Nigel P. Gravells, Public Purpose Trusts, 40 MOD. L. REV. 397, 406 (1977); William Schwartz, Comment, Wills-Revocation by Divorce-The Doctrine of "Changed Circumstances": Younker v. Johnson, 34 B.U.L. REV. 395, 396 (1954) ("[I]n absence of statute, it is generally agreed that a divorce, unaccompanied by a property settlement, does not revoke the legacy in favor of the divorced spouse.”).

15. O’Toole v. Cent. Laborers' Pension \& Welfare Funds, 299 N.E.2d 392, 394 (Ill. 1973); Annotation, Divorce Decree Purporting to Award Life Insurance to Husband as Terminating WifeBeneficiary's Rights Notwithstanding Failure to Formally Change Beneficiary, 7o A.L.R.3D 348, 349 (1976). Michigan's statute was similarly gender-based, but shows the origins of divorce revocation statutes. It provided that "every decree of divorce shall determine all rights of the wife in and to the proceeds of any policy or contract of life insurance . . . unless otherwise ordered in said decree such policy or contract shall thereupon become and be payable to the estate of the husband or to such named beneficiary as he shall affirmatively designate.” 1939 Mich. Pub. Act. No. 220 (codified at Mich. Comp. Laws. Sec. 552.101 (noted in Minnesota Mut. Life Ins. Co. v. Hendrick, 25 N.W.2d 189, 191 (Mich. 1946)); Prudential Ins. Co. of Am. v. Irvine, 61 N.W.2d 14, 15 (Mich. 1953). 
the other spouse's estate served as a renunciation of any benefits provided in a preexisting will. ${ }^{16}$

Moreover, the 1969 UPC provided that while marriage does not revoke a premarital will, ${ }^{17}$ divorce serves to revoke any provisions in a will concerning the ex-spouse. ${ }^{18}$ The 1969 UPC permitted the presumption to be rebutted only if the will expressly provided otherwise. ${ }^{19}$ The presumption thus served as something of a back-up in case a separation agreement did not provide for a waiver of all rights. This first UPC version of the presumption focused on provisions in a will in favor of the "former spouse" and did not, extend the presumption to the ex-spouse's relatives; indeed, some commentators suggested that such an extension would be unwarranted. ${ }^{20}$

16. UNIF. Probate Code $\$$ 2-204 (UNIF. LAW COMM’N 1969), 8 U.L.A. 187 (2013) (current version at UNIF. PRobate CODE $§$ 2-213 (UNIF. LAW COMM'N, amended 2010)). The comment explains that this provision, permitting waiver of:

[A]ll statutory rights in the other spouse's property seem [s] desirable in view of the common and commendable desire of parties to second and later marriages to insure that property derived from prior spouses passes at death to the issue of the prior spouses instead of to the newly acquired spouse. The operation of a property settlement as a waiver and renunciation takes care of the situation which arises when a spouse dies while a divorce suit is pending.

$I d$. $\mathrm{cmt}$. (cmt. repealed 2013). Note that the underlying assumption is that this will be most useful in case of divorce in a second marriage. It is true that the divorce rate for subsequent marriages is higher than the divorce rate for a first marriage. See Alison Aughinbaugh et al., Marriage and Divorce: Patterns by Gender, Race, and Educational Attainment, U.S. DEP'T OF LABOR: BUREAU OF LABOR STATISTICS (Oct. 2013), https://www.bls.gov/opub/mlr/2013/article/marriage-anddivorce-patterns-by-gender-race-and-educational-attainment.htm. Many family law separation agreements provide for exactly such a waiver.

17. See Unif. Probate Code $§ 2-508$ (Unif. LAW Comm’n 1969) (amended 2010). It does protect a pretermitted spouse (a spouse omitted from the premarital will). See $i d$. at $\$ 2-301$. The section number remains the same in the current UPC, but the circumstances have been clarified. See id. at $\$ 2-508 \& \mathrm{cmt}$. (amended 2010) (stating that unless provided for elsewhere, changing circumstances does not change or revoke any part of a will).

18. The 1969 version of the UPC provided that divorce:

$[R]$ evokes any disposition or appointment of property made by the will to the former spouse, any provision conferring a general or special power of appointment on the former spouse, and any nomination of the former spouse as executor, trustee, conservator, or guardian, unless the will expressly provides otherwise. Property prevented from passing to a former spouse because of revocation by divorce or annulment passes as if the former spouse failed to survive the decedent, and other provisions conferring some power or office on the former spouse are interpreted as if the spouse failed to survive the decedent. If provisions are revoked solely by this section, they are revived by testator's remarriage to the former spouse. . . . A decree of separation which does not terminate the status of husband and wife is not a divorce for purposes of this section.

Id. at $\$ 2-508$. This form of the revocation statute is still in effect in some states. See, e.g., KY. REV. STAT. ANN. $\$ 394.092$ (West 2010).

19. See Unif. PRobate CODE $§ 2-508$.

20. Richard V. Wellman \& James W. Gordon, Uniformity in State Inheritance Laws: How UPC Article II Has Fared in Nine Enactments, 1976 BYU L. REV. 357, $3^{85}$ (1976) (“[M]any may quarrel 
Furthermore, in jurisdictions that adopted this version of the revocation upon divorce statutes, courts typically did not extend their coverage to include nonprobate assets unless those assets were addressed explicitly in a property settlement agreement. ${ }^{21}$

Just over two decades later, the 1990 UPC extended the broad revocation upon divorce policy to include the ex-spouse's relatives and made the revocation effective for nonprobate assets. ${ }^{22}$ As with the 1969 UPC, the will might have been made before or after marriage. ${ }^{23}$

If the 1969 UPC provision reflected changing marriage trends and a desired "clean break" at divorce, the 1990 revision not only expanded on

with the implicit assumption-that divorce usually ends all contact and emotional ties between the testator and issue of his ex-spouse-that justifies the conclusion that a testator would not continue to intend to provide for the ex-spouse's issue. In some circumstances, revocation of gifts to a spouse's issue because of divorce undoubtedly reflects intention . . . . But considerable doubt would attend the revocation of gifts to a spouse's issue when the devise is to an individual by name and does not refer to the relationship between the devisee and the spouse. . . It seems doubtful that other states will want to follow this deviation .... [T] he notion of extending revocation by operation of law can be challenged as an unwise legislative venture into the motives of testators concerning their reasons for choosing the beneficiaries named in wills. After a testator dies, guesswork about why he wrote the will that he left unrevoked at death should be discouraged whenever possible."); see McGuire v. McGuire, 631 S.W.2d 12, 13-14 (Ark. 1982) (divorce did not revoke residuary clause in favor of stepchildren); Wright v. Cornish, No. 2015-CA-OO13O1-MR, 2017 WL 65445, at $*_{5}$ (Ky. Ct. App. Jan. 6, 2017) (Vanmeter, J., dissenting) ("The remainder to the two named and identified step-children contains no ambiguity. At the time the will was written, they were his step-children ... . The will contains no conditional bequest/devise. The fact that he subsequently divorced obviously revoked any benefit to his ex-wife, but does not change the bequest/devise to these two named individuals.").

21. Lawrence W. Waggoner, Spousal Rights in Our Multiple-Marriage Society: The Revised Uniform Probate Code, 26 REAL Prop., Prob. \& TR. J. 683, 690 n.12 (1992) (“Apart from statute, divorce decrees and separation agreements are usually held not to revoke life-insurance or similar beneficiary designations of a former spouse unless they say so specifically.”).

22. The 1990 version of the UPC also renumbered the revocation-upon-divorce section. UNIF. Probate CODE $§$ 2-804 (amended 2010) (formerly UnIf. Probate CODE $§ 2-508$ (1969)). The comment to Code $\$ 2-804$ explains: "The revisions of this section, pre-1990 Section 2-508, intend to unify the law of probate and nonprobate transfers. As originally promulgated, pre-199o Section $2-508$ revoked a predivorce devise to the testator's former spouse. The revisions expand the section to cover "will substitutes" such as revocable inter-vivos trusts, life-insurance and retirement-plan beneficiary designations, transfer-on-death accounts, and other revocable dispositions to the former spouse that the divorced individual established before the divorce (or annulment)."

23. See Adam J. Hirsch, Inheritance on the Fringes of Marriage, 2018 U. ILL. L. REV. 235, 248 (2018) (hereinafter Hirsch, Inheritance on the Fringes). 
those themes, ${ }^{24}$ but also incorporated the nonprobate revolution. ${ }^{25}$ As it stands, the UPC provides that the presumption can be rebutted in a narrow range of circumstances, including if "the will expressly provide[d] otherwise." ${ }^{26}$ However, the presumption itself only applies to divorce. ${ }^{27}$ When relationships dissolve between nonmarital couples, there is no impact on any beneficiary designations (although couples in registered domestic partnerships or civil unions are covered in some states if the domestic partnership or civil union status confers the same rights as if the couple were married). ${ }^{28}$

Today, in almost all U.S. states, a marriage does not revoke a will, ${ }^{29}$ but a final divorce settlement or annulment of a marriage revokes all provisions in the will in favor of the former spouse either via case law or statute. $3^{\circ}$ This

24. Lawrence Waggoner explains " $[\mathrm{t}]$ he rationale is that the divorce process severely weakens any ties between the transferor and the former spouse's relatives." Waggoner, supra note 21 , at 695 . Waggoner also notes the distinction between revocation upon divorce and revocation upon murder, which does not result in such a broad revocation: "The rationale for the distinction between divorce and murder is that, in the case of divorce, the relatives of each former spouse are likely to side with that former spouse. A murderer's relatives, however, are as likely to sympathize with the murderer's victim as with the murderer." Lawrence W. Waggoner, The Multiple-Marriage Society and Spousal Rights Under the Revised Uniform Probate Code, 76 IOWA L. REV. 223, 229 n.19 (1991). But see Hirsch, supra note 1, at 649 ("This doctrinal asymmetry represents a logical flaw in the Code.").

25. As Robert Whitman explained it, the expansion appeared "warranted" based on "the increasing use of . . nonprobate transfers." Whitman, supra note 4, at 1054 . See also Lawrence W. Waggoner, The Creeping Federalization of Wealth-Transfer Law, 67 VAND. L. REV. 1635, 1638 (2014) ("The 1990 UPC revisions took the logical step of extending the revocation-on-divorce provision of the 1969 UPC to nonprobate transfers.").

26. UNIF. Probate Code $§ 2-508$ (UNIF. LAW COMM'N 1969). Although "express terms" is not defined in UPC $\$ 2-804$ nor in its Comments, similar language is used in other UPC Sections. See, e.g., UNIF. PROBATE CODE $\$$ 2-101 cmt. (amended 2010) ("A clear case would be one in which the decedent's will expressly states that an individual is to receive none of the decedent's estate. Examples would be testamentary language such as 'my brother, Hector, is not to receive any of my property' or 'Brother Hector is disinherited.'”).

27. See id. $\$ 2-804(\mathrm{~b})$.

28. E.g., N.J. STAT. ANN. 37:1-31 (a) (West Supp. 2017) ("Civil union couples shall have all of the same benefits, protections and responsibilities under law, whether they derive from statute, administrative or court rule, public policy, common law or any other source of civil law, as are granted to spouses in a marriage."). For discussion of the UPC and nonmarital couples, see, e.g., T.P. Gallanis, Inheritance Rights for Domestic Partners, 79 TuL. L. REV. 55, 85 (2004); E. Gary Spitko, An Accrual/Multi-Factor Approach to Intestate Inheritance Rights for Unmarried Committed Partners, 81 OR. L. REV. 255, 345-49 (2002); Spitko, supra note 4, at 1068.

29. It still does in a few states. See Kim Kamin, Am. LAw Inst. Continuing Legal Educ., PlanNING FOR THE 5o\%: DIVORCE AND BleNDED FAMILIES, SWo2 ALI-CLE 469 , at 20 n. $14(2015)$ (listing four states); Hirsch, Inheritance on the Fringes, supra note 23, at $242 \mathrm{n} .35$ (same).

3o. E.g., ME. REV. STAT. ANN. tit. 18-A, § 2-508 (2017) (limiting applicability to divorce and probate assets only); see Estate of Chaney v. Chaney, No. 2015-CA-01613-COA, 2017 WL 2123982 , at $*_{3}$ (Miss. Ct. App. May 16, 2017) (where "the [Mississippi] supreme court recognized that a will may be revoked by various circumstances, not specified within the statute" but "'declined [sic] to adopt a rule of automatic revocation' in instances where a predivorce will and a subsequent property-settlement agreement are in conflict" (quoting Hinders v. Hinders, 
includes transfers of property, rights to determine who receives property, and nominations to serve in fiduciary roles such as executor of the will or trustee of a testamentary trust. Only provisions relating to the ex-spouse (and family members) are revoked; the will otherwise remains intact. $3^{1}$ This means that the property passes as if the spouse had predeceased the testator. ${ }^{22}$ Like the UPC, many states also apply this rule of revoking probate-related gifts and appointments to nonprobate transfers such as revocable trusts and beneficiary designations. Again, the presumption can be rebutted, but only in limited circumstances.

Yet, there is some variation throughout the states, not just as to which beneficiary designations are revoked, 33 but also with respect to the application of the presumption itself: (1) virtually all states have explicit revocation on divorce statutes that apply either rebuttable or irrebuttable presumptions; 34 and (2) at least one state has no revocation on divorce statute and no implementation of implied revocation on divorce, using instead a contextual analysis that considers the post-divorce facts and circumstances. 35

In addition, states vary on whether the revocation applies to nonprobate transfers and covers the ex-spouse's family members. Moreover, notwithstanding their seeming breadth, state revocation upon divorce statutes are preempted by federal law for a large number of pension plans, health and

828 So.2d 1235, 1235 (Miss. 2002))). Mississippi may, however, be the only state that does not revoke any type of gift to the surviving ex-spouse. See MISS. CODE ANN. $\$ 9^{1-5}-3$ (2013). In the District of Columbia, "divorce alone of the testator (or testatrix) [may] not [be] enough ... to cause revocation of the will by implication; the spouses must have 'settled their respective rights in each other's assets." Estate of Reap v. Malloy, 727 A.2d 326, 329 (D.C. 1999) (quoting Estate of Liles v. Liles, 435 A.2d 379, 382 (D.C. 1981)). Nonetheless, "[t] he existence of a property settlement agreement or court division of the property is . . conclusive." Id. at 330 .

31. See UnIF. Probate Code $\$ 2-804(\mathrm{~d})$.

32. See id. $\$ 2-804$.

33. For example, Virginia provides for revocation of any "revocable beneficiary designation" except for those in a trust. VA. CODE ANN. § 20-111.1 (2016).

34. E.g., see CAL. Prob. CODE $\$ 6227$ (West 2009); Brimmer, supra note 4, at 976; Hirsch, Inheritance on the Fringes, supra note 23 , at 241-42.

35. See Hinders v. Hinders, 828 So. 2d 1235, 1238 (Miss. 2002). In Mississippi, "[g]enerally a divorce accompanied by a property settlement agreement which is fully carried out according to its terms should have the effect of revoking a prior will in favor of a former spouse, especially where the parties thereafter sever all ties." Rasco v. Estate of Rasco, 501 So. 2d 421, 424 (Miss. 1987) (quoting In re Estate of Perigen, 653 S.W.2d 717, 720 (Tenn. 1983)) (internal quotation marks omitted). For example, Kay and Richard Rasco were divorced in April 1982. Id. at 422. After the divorce, Kay and Richard continued to live together, even sleeping in the same bed. Id. After Richard's death, his pre-divorce will was found in a safe at his house, bequeathing most of his estate to Kay. Id. The court found that based on the "facts and circumstances of this case ... and the conduct of the parties," there was no implied revocation of the will. Id. at 424 . For a discussion on implied revocation upon divorce, see Hirsch, Inheritance on the Fringes, supra note 23, at 242 n.33. As indicated supra note 3o, the District of Columbia does not appear to have a statute that revokes a will upon divorce. See D.C. Code Ann. § 18-109 (West 2018) and annotations thereto. 
life insurance plans, and other employee benefits. ${ }^{36}$ In fact, in reviewing states' attempts to apply revocation upon divorce statutes to such federallyregulated benefits, the Supreme Court has repeatedly shielded those assets. 37 It has reiterated the importance of paying the proceeds to the "named beneficiary" and the decedent's "right freely to designate the beneficiary and to alter that choice at any time by communicating the decision in writing to the proper office" $3^{8}$ rather than having that choice altered by state override statutes.

\section{B. PRESUMPTIONS OF REVOCATION-UPON-DIVORCE STATUTES}

The underlying assumption is that revocation-upon-divorce provisions reflect the decedent's intent to terminate all connections with the ex-spouse and, more recently, the ex-spouse's relatives. 39 This termination, under the UPC and an increasing number of state statutes, includes both probate and nonprobate designations. As the Supreme Court explained, "a legislature could have thought that" such a rule covering nonprobate assets "would be more likely to align with most people's intentions." $4^{\circ}$ Similarly, Professors Leslie and Sterk argue that the failure to extend the presumption to "non-

36. The ERISA statute provides that it "shall supersede any and all State laws insofar as they may now or hereafter relate to any employee benefit plan.” 29 U.S.C.A. $\$ 1144$ (a) (West 2012); see generally Hillman v. Maretta, 569 U.S. 483, 493 (2013) (striking down Virginia divorcerevocation statute that attempted a work-around ERISA preemption by providing a cause of action against the ex-spouse for the proceeds from the policy that would otherwise have been revoked in the absence of preemption); Kennedy v. DuPont Sav. \& Inv. Plan, 555 U.S. 285,289 (2009) (finding divorce decree explicitly divested the wife of any rights in a retirement plan, pension plan, or like benefit program; the Supreme Court nonetheless held that the terms of the ERISA plan documents controlled). See also Egelhoff v. Egelhoff ex rel. Breiner, 532 U.S. 141 (2001) (holding that Washington divorce revocation statute was preempted with respect to ERISA-covered life insurance and pension plan naming ex-spouse as beneficiary). As a result of the Court's approach to federally-regulated nonprobate assets, an ex-spouse is not entitled to probate assets or assets covered by state law (such as bank accounts), but would be entitled (if listed as a beneficiary) to a pension plan covered by ERISA. See Melanie B. Leslie \& Stewart E. Sterk, Revisiting the Revolution: Reintegrating the Wealth Transmission System, 56 B.C. L. REV. 61,68 $(2015)$. This exemption is significant: for example, $\$ 8.3$ trillion in private pension plans are covered by ERISA and thus exempted from state law coverage. EMP. BENEFITS SEC. ADMIN., DEP'T. of Labor, Private Pension Plan Bulletin 1 (2016).

37. See Waggoner, supra note 24 , at 1642 . Professor Waggoner notes "[s]adly," that "the Supreme Court has destroyed the UPC's intent-effecting divorce-revocation rule for federally authorized or regulated nonprobate payments." Id.

38. Hillman, 569 U.S. at 484 (quoting Ridgway v. Ridgway, 454 U.S. $46,5^{6}$ (1981)).

39. E.g., Alexander A. Boni-Saenz, Distributive Justice and Donative Intent, 65 UCLA L. REV. (forthcoming 2018) (manuscript at 33), available at https://ssrn.com/abstract=30oo630; Gary, supra note 2, at 101. Professor Gary notes that the emergence "of a multiple-marriage society means that ever greater numbers of decedents may die following divorce and remarriage without changing beneficiary designations ... after the divorce." See id. For an explanation of the expansion to the ex-spouse's relatives, see, e.g., Waggoner, supra note 20, at 689-701.

40. Hillman, $5^{69}$ U.S. at 495 . 
probate assets often frustrates the divorced decedent's intent." ${ }^{1}$ For example, as the children argued in 2016 in an Eighth Circuit case concerning a life insurance policy, their ex-stepmother should not benefit because their father never spoke of her after the divorce and "wanted a clean slate." $4^{2}$ Indeed, they reported that although the ex-stepmother attended the funeral, "she was not well received by his family because they believed she was unfaithful to [him] during the marriage." 43 By contrast, the ex-stepmother claimed that she and her ex-husband were still friendly at the time of his death. 44

\section{HOW COURTS APPLY REVOCATION-UPON-DIVORCE STATUTES}

When courts-in the United States and elsewhere-interpret revocationupon-divorce statutes, they typically apply a bright-line rule, even when faced with a set of contradictory facts. 45 At times, the presumption appears virtually irrebuttable. Consider a few examples of how courts apply the presumption. Jesse and Virginia Lee Suiters, who were married in $196_{5}$, entered into a voluntary separation agreement in $1996.4^{6}$ While the agreement provided that each party waived rights in the other's estate, it also stated: "[n] otwithstanding the mutual releases set forth in this paragraph, either party to this Agreement may, by his or her Last Will and Testament, give, devise or bequeath any part or all of his or her estate to the other." 47 The couple did not divorce until 2006, and Jesse died shortly thereafter. His 2003 will, which was drafted seven years after the separation agreement, devised his residuary estate to "Virginia Lee Suiters." $4^{8}$

The applicable Maryland statute presumes revocation upon divorce "unless otherwise provided in the will or decree." 49 The majority of the court concluded, after considerable discussion of Maryland and out-of-state authority, that the Maryland legislature's intent was to protect a testator who neglects to change a will following divorce or annulment. $5^{\circ}$ This legislative

41. Leslie \& Sterk, supra note 35, at 67-68; Sterk \& Leslie, supra note 5, at 180. See also David J. Feder \& Robert H. Sitkoff, Revocable Trusts and Incapacity Planning: More Than Just A Will Substitute, 24 ELDER L.J. 1, 14 (2016) (identifying revocation upon divorce as an "intentimplementing rule[] of construction"); Hirsch, supra note 1, at 653 ("[T] he Commissioners wisely apply their rule of implied revocation for pre-dissolution wills to will substitutes as well”).

42. Response Brief of Appellees at 7-8, Metro. Life Ins. Co. v. Melin, 853 F.3d 410 (8th Cir. Mar. 31, 2016) (No. 16-1172).

43. Id. at 11 .

44. Id. at 8 .

45. This also means, for example, that if the statutory provision only applies to probate assets, courts usually struggle when issues are raised concerning nonprobate assets. See Clymer v. Mayo, 473 N.E.2d 1084, 1093 (Mass. 1985); Sterk \& Leslie, supra note 5, at 207.

46. Nichols v. Baer ex rel. Suiter, 78 A.3d 344, 346 (Md. 2013).

47. Id. at 347 .

48. Id.

49. Id. at 346 (quoting MD. Code AnN., Est. \& Trusts, § 4-105 (4) (West 2014)).

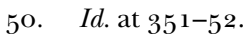


intent, the majority concluded, "is best achieved by an automatic revocation of the relevant provisions of the testator's pre-existing will." $5^{1}$ Consequently, Virginia Lee was unable to benefit from Jessie's residuary estate designation in the 2003 will. $5^{2}$

The dissent instead focused on the testator's intent, emphasizing the language of the separation agreement that allowed the parties to devise property to one another and the fact that Jessie's will devised his residuary estate to "Virginia Lee Suiters" without describing this bequest as to his "wife." 53 In addition, the dissent criticized the majority for relying on cases from other states interpreting the UPC's more restrictive language. 54

In 2007, an Arkansas court recognized that the decedent intended for his ex-spouse to inherit his entire estate, but held that the divorce revocation statute rendered the decedent's intent irrelevant. 55 Donald R. Langston, the decedent, was a retired Arkansas circuit judge. $5^{6}$ His will was dated after the circuit court had announced the Langstons' divorce settlement from the bench-but before the court entered the official divorce decree.57 The Arkansas statute bluntly stated that any provisions in favor of an ex-spouse in a pre-divorce will are revoked. $5^{8}$ The court held that, even though the exspouses had keys to one another's houses, ate meals together, and Donald paid many of his ex-wife's post-divorce bills, his intent could not be considered in derogation of the plain meaning of the statute. 59

In In re Estate of Pekol, ${ }^{60}$ the testator executed her will in 1957, bequeathing all of her real and personal property to her husband. Although the couple divorced in 1961 , they cohabited for thirteen years prior to her death in 1983. An Illinois appellate court held that the testator's will was revoked; consequently, "the divorce decree 'forever barred' her ex-husband

\footnotetext{
$5^{1 .} \quad I d$. at $35^{2-53}$.

52. See id. at $353-54$.

53. Id. at $355^{-5} 5^{6}$.

54. Id. at $357-58$.
}

55. Langston v. Langston, 266 S.W.3d 716, 721-22 (Ark. 2007). With respect to joint wills, courts treat them somewhat differently. Compare, e.g., In re Murray, 921 N.Y.S.2d 161, 168-69 (N.Y. App. Div. 2011 ) (examining the intent of decedent and her ex-husband in holding that, notwithstanding their divorce, decedent's ownership interest in condominium was subject to provision of joint will calling for all property over which decedent had "power of disposal" to pass to her former husband), with In re Estate of Pence, 327 S.W.3d 570, 574-76 (Mo. Ct. App. 2010) (holding, in light of Missouri state statutory provisions, that divorce between joint testators revoked all provisions in the joint will in favor of the surviving testator's interest in the decedent's property, in spite of the intent indicated by the will's anti-revocation clause).

56. Donald R. Langston, FIND A GRAVE, https://www.findagrave.com/cgi-bin/fg.cgi?page $=$ gr\&GRid=13556294 (last visited Apr. 27, 2018).

57. Langston, 266 S.W.3d at 718.

58. Id. at $720-21$.

59. Id. at $721-22$.

6o. In re Estate of Pekol, 499 N.E.2d 88, 89 (Ill. App. Ct. 1986). 
from claiming any part of her estate." ${ }_{11}$ "Despite the couple's thirteen-yearlong cohabitation, the court asserted that there was 'strong public policy' favoring the institution of marriage" rather than a cohabitant who had been technically divorced from the decedent. ${ }^{62}$

\section{REBUTTING THE PRESUMPTION}

As the courts recognized, the presumption can be rebutted. There are only three ways under the UPC and many state codes to do so: a contrary intent must appear from "the express terms of a governing instrument, a court order, or a contract relating to the division of the marital estate made between the divorced individuals before or after the marriage, divorce, or annulment." $6_{3}$ Beyond the sparse words of the statute, the UPC does not provide any commentary on what evidence might be adequate. However, this bright-line rule certainly enhances the goal of administrative convenience, resulting in fewer evidentiary hearings and more stream-lined probate proceeding, thereby expediting distribution.

Not surprisingly, in light of statutory language and limited commentary, the presumption is rarely rebutted. Even where there is a premarital will that names a future-and now "ex-spouse"-the ex-spouse is typically precluded from taking. ${ }^{64}$ As the Supreme Court of South Dakota explained, in order to overcome the state's revocation upon divorce provision, "the governing instrument [must] contain express terms referring to divorce, specifically stating that the beneficiary will remain as the designated beneficiary despite divorce." $6_{5}$ Inaction, such as failing to change the beneficiary after divorce, does not rebut the presumption. ${ }^{66}$ On the other hand, some states will permit

61. Brimmer, supra note 4 , at 978 .

62. Id.

63. Unif. Probate Code $\$$ 2-804(b) (Unif. LaW Comm'n 2010); accord Restatement (Third) OF Prop.: Wills AND Other DONATIVE Transfers $\$ 4.1$ (AM. LAW INST. 1999).

64. E.g., In re Estate of Forrest, 706 N.E.2d 1043, 1047 (Ill. App. Ct. 1999); see Susan N. Gary, The Probate Definition of Family: A Proposal for Guided Discretion in Intestacy, 45 U. MICH. J.L. \& REFORM 787,789 n.11 (2012).

65. Buchholz v. Storsve, 740 N.W.2d 107, 112 (S.D. 2007); cf. Lincoln Benefit Life Co. v. Guerrero, Civ. No. 14-1077 JCH/WPL, 2016 WL 4547157 , at *7 (D.N.M. June 27, 2016) (allowing rebuttal evidence, but finding evidence consisting only of ex-wife's statements to be insufficient); Am. Gen. Life Ins. Co. v. Jenson, Civ. No. 11-5057-JLV, 2012 WL 848158, at *8 (D.S.D. Mar. 12, 2012) (distinguishing Buchholz, where there was no evidence of the decedent's intent to benefit her ex-spouse, from Jenson, where the ex-husband verbally stated his intent to his financial advisor). In Jenson, the District Court of South Dakota, like other courts, treated the revocation upon divorce statutes as a rule of construction that could be rebutted. Id. at *14-15.

66. E.g., In re Estate of Lamparella, 109 P.3d 959, 966 (Ariz. Ct. App. 2005) (“[T]he purpose of [the statute] would be eviscerated if a former spouse could circumvent the automatic revocation effected by the statute by submitting self-serving testimony that the decedent spouse's inaction reflected an intention to revive his or her designation of the ex-spouse as the beneficiary. ... [The decedent spouse] was required, if the statute is to have any effect, to confirm that decision in writing ....”). 
extrinsic evidence to rebut the presumption. Wisconsin explicitly allows extrinsic evidence to show an intent to rebut the presumption ${ }^{6} 7$ while in Alaska, the courts have read such an exception into the statute. Consider the case of John and Jane Davis as an example of how this exception used by the Alaskan courts works. The couple was married for almost 30 years; after their divorce, John told his life insurance agent that he wanted Jane to remain the beneficiary of his life insurance policy (worth more than \$200,ooo after his death). ${ }^{68}$ Because Jane was already the named beneficiary, the agent did not believe that John needed to fill out a new beneficiary designation form. ${ }^{69}$ The court found that Alaska's revocation-upon-divorce statute created only a rebuttable presumption of revocation, "not a strict and inflexible rule." $7^{\circ}$ Although John had only expressed his preferences orally, the court held it was admissible non-hearsay evidence that rebutted the statutory presumption of revocation. $7^{1}$

Based on this survey of the revocation upon divorce presumption, the next section turns to issues surrounding the ongoing utility of the presumption based on changes in society's understanding of divorce and postdivorce relationships and the populations affected by divorce revocation.

\section{Policy: COllaborative Divorce, Gender, AND Class}

The primary policy goal of trusts and estates law-and of the revocation upon divorce statutes-is effectuating the decedent's intent. Yet the policy of a virtually automatic revocation upon divorce may not be justifiable. First, new developments in divorce law call into question assumptions about the decedent's intent. Second, the sociology of post-divorce relationships and

67. "If the transfer is made under a governing instrument and the person who executed the governing instrument had an intent contrary to any provision in this section, then that provision is inapplicable to the transfer. Extrinsic evidence may be used to construe the intent." WIS. STAT. ANN. $§ 854.15(5)$ (West Supp. 2016). But see Johnson v. Blodgett, 745 N.W.2d 88, No. $2007 \mathrm{AP} 8{ }_{3} 6-\mathrm{FT},{ }_{2007} \mathrm{WL} 4390393$, at ${ }_{2}$ (Wis. Ct. App. Dec. 18, 2007) (unpublished table decision) (recounting types of testimony considered under the statute); Dahm v. City of Milwaukee, 707 N.W.2d 922, 925 (Wis. Ct. App. 2005) (holding that opinions stated by two witnesses did not constitute the "specific facts' as required by [the statute]" (quoting WIS. STAT. ANN. § 802.08(3) (West 2008)). Howard Erlanger explained the statute, stating: "Of course, a person who wants a different result can provide for it in an estate plan made after the divorce; in addition, extrinsic evidence can be presented to rebut the presumption in the statute." HOWARD S. ERLANGER, Wisconsin's New Probate Code 48 (1998).

68. State Farm Life Ins. Co. v. Davis, No. 3:07-Cv-oo 164 JWS, 2008 WL 2326323, at $*_{1}$ (D. Alaska June 3, 2008). But see In re Estate of Lamparella, 109 P.3d at 966-67 (requiring such evidence be in writing). Note that the Davis court was a federal court interpreting a state statute that was based on the 1990 UPC. See Davis, 2008 WL 2326323 , at $*_{2}$.

69. Davis, 2008 WL 2326323 , at $*_{1}$.

7o. See id. at $* 4$.

71. Id. at $*_{2-3}, *_{5}$. The Davis court cited another case involving whether a revocation statute applied when a marriage had been declared invalid after the husband's death; rather than apply the statute, the Rodriguez court held that the beneficiary designation was irrevocable upon the husband's death. Id. at $*_{3}$ (citing In re Estate of Rodriguez, 16o P.3d 679, 686 (Ariz. Ct. App. 2007)). 
caretaking similarly show that the end of a marriage does not necessarily mean the end of the bond. Finally, the revocation-upon-divorce statutes have various (presumably unintentional) gender and class implications.

\section{A. DIVORCE PROCESS CHANGES}

Since the original UPC and its revocation-upon-divorce provision, the divorce process has changed, moving toward a more therapeutic model. $7^{2}$ With the widespread adoption of no-fault divorce in the 1970s, the legal divorce process has moved away from mud-slinging court cases, where one spouse was required to prove the other's fault in order to be granted a divorce.73 By 2010 , all states allowed the possibility of a some form of no-fault divorce, with some allowing only no-fault, and others grafting no-fault provisions into the pre-existing fault system. 74

From the beginning, no-fault divorce has been tied to the "recogni[tion] that abolishing fault entirely from divorce would require new procedures to manage family dissolution." 75 Indeed,

The original California no-fault divorce plan . . included a plan for a unified family court that would provide divorce counseling in lieu of declaring one (and only one) party at fault and establish a new, less acrimonious basis for reconstituting families. The plan combined both substantive legal reform and procedural court reform; just as the substantive law was designed to minimize artifice and conflict, so too were the accompanying new procedures. $7^{6}$

When the California legislature adopted the no-fault reforms, however, it was "unwilling to pay for them"; the result was a substantive change in the

72. Murphy \& Singer, supra note 9, at 23-24; Naomi Cahn \& June Carbone, Reality and the Family Courts, 28 J. Am. Acad. Matrim. Law. 309, 310 (2015) (reviewing JANE C. MurPHY \& JANA B. SINGER, DIVORCED FROM REALITY: RETHINKING FAMILY DISPUTE RESOLUTION (2015)).

73. JoAnna L. Grossman \& LaWrence M. Friedman, Inside the Castle: LaW and the FAMILY IN 2OTH CENTURY AMERICA 1 77-78 (201 1); see also Deborah H. Bell, The Cost of Fault-Based Divorce, 82 MISS. L.J. SUPRA 131, 135 (2013) (noting that in Mississippi, in the absence of "consent, the parties are relegated to a fault-based divorce system that has changed very little in the last century").

74. GROSSMAN \& FRIEDMAN, supra note 72, at 177-79; see also Bell, supra note 72 , at 142 (regarding states without no-fault divorce, "Mississippi stands alone").

75. Cahn \& Carbone, supra note 71, at 309 .

76. Id. at 309 (footnote omitted). See also Richard C. Dinkelspiel \& Aidan R. Gough, The Case for a Family Court - a Summary of the Report of the California Governor's Commission on the Family, 1 FAM. L.Q. 7o, 80-81 (1967) (explaining that courts should act in the best interest of a child in a divorce proceeding, when applicable); Herma Hill Kay, A Family Court: The California Proposal, $5^{6}$ CALIF. L. REV. 1205 , $1225^{-28}$ (1968) (discussing California's use of divorce counseling in their family court procedures). 
law, "without equipping the courts with the ability to deal with them" by offering therapeutic services. 77

Nevertheless, the development of the no-fault regime has resulted in a paradigm shift in family law. Lawyers are now supporting clients to become more engaged in a legal matter, "develop[ing] techniques that encourage cooperative problem-solving ... (for example, collaborative divorce practices)." $7^{8}$ Lawyers aid clients in preventing conflict when they provide information about the process of dispute resolution. 79 Moreover, "lawyers may even play a role as healers, helping clients '(re)build a parenting partnership when they encourage non-adversarial dispute resolution options." 80 This change is similar for judges, "[j] udges no longer simply resolve disputes, but also become involved in he families by, for example working with interdisciplinary teams to address not just the family's legal needs but also its emotional functioning and recovery." ${ } 1$

Changes in custody have also greatly affected the modern divorce process. This may result in more cooperative ex-relationships These changes not only encourage shared post-divorce parenting, but also move away from traditional custody labels in favor of detailed parenting plans that specify how divorcing and separating parents will continue to share both legal decisionmaking and day-to-day caretaking responsibilities for children. ${ }^{82}$ Indeed, the Model Parenting Plan drafted by the American Academy of Matrimonial Lawyers avoids any mention of "custody" or "visitation," intending this choice of language "to send an important message to parents about their ongoing responsibility and [to be] more reflective of what actually happens in families." ${ }_{3}$ The increasing use of joint custody is yet another example of this development.

Wendy Paris, the author of Splitopia: Dispatches from Today's Good Divorce and How to Part Well, explained how important it was for her, her ex-husband, and their son to stay close:

77. Cahn \& Carbone, supra note 71, at 309-10. See J. Herbie DiFonzo, No-Fault Marital Dissolution: The Bitter Triumph of Naked Divorce, $3_{1}$ SAN DIEGO L. REV. 519, 541-43, 546-49 (1994).

78. Cahn \& Carbone, supra note 71 , at 313 (alteration in original). See Why States Should Adopt the UCLA, UNIF. LAW COMM'N, http://www.uniformlaws.org/Narrative.aspx?title=Why\% 20States \% 20Should \% 20Adopt\% 20the\% 20UCLA (last visited Apr. 27, 2018) ("Collaborative law is a voluntary, client-driven form of alternative dispute resolution practiced in all 50 states. It has been widely used in family law cases.”).

79. Cahn \& Carbone, supra note 71 , at 313.

8o. Id. (citing MURPHY \& SINGER, supra note 9, at 93 (citation omitted)).

81. Id.

82. See J. Herbie DiFonzo, From the Rule of One to Shared Parenting: Custody Presumptions in Law and Policy, 52 FAM. CT. REV. 213, 225-26 (2014); Jana B. Singer, Bargaining in the Shadow of the Best-Interests Standard: The Close Connection Between Substance and Process in Resolving Divorce-Related Parenting Disputes, 77 L. \& ConTEMP. Probs. 177, 188 (2014).

83. Mary Kay Kisthardt, The AAML Model for a Parenting Plan, 19 J. AM. ACAD. MATRIM. LAW. $223,229(2005)$. 
I was totally committed to the idea of him remaining connected to both [of] us in an easy, natural way .... [W] e've all moved to Los Angeles. It was really important to my ex that we live within walking distance of each other ... . I was much nicer to him the minute he moved out. ${ }^{8}$

Yet, if divorce is becoming more collaborative and techniques such as mediation are changing the hostile nature of the transaction and the ensuing relationships, the UPC is not only going in a different direction but it is doubling down by adding in family members to the category of those who are excluded upon divorce. Courts are similarly adopting a hard line when they refuse to look to extrinsic evidence of the testator's intent. As a result, probate law is becoming increasingly rigid and grounded in a "clean break" approach ${ }^{8}$ while family law has realized that a clean break is neither plausible (consider the movement toward co-parenting, etc.) nor even desirable in all cases. ${ }^{86}$ Indeed, legislatures and courts are adopting rigid stances presumably in the name of donor intent but-as discussed in the next section-donor intent is not as easy to gauge as previously thought.

\section{B. RELATIONSHIPS BETWEEN EX-FAMILY MEMBERS}

In Homeward Bound: Modern Families, Elder Care, and Loss, our study of how grown children cared for their dying Baby Boomer parents, Amy Ziettlow ${ }^{87}$ and I heard numerous stories of strained relationships between ex-family members and between former stepparents and stepsiblings. ${ }^{88}$ Yet, to our surprise, we also heard many stories in which ex-family members sustained strong ties. In one-fifth of the families in our study where there had been a divorce, the ex-spouse assumed some caregiving role, ranging from

84. Spotlight: Wendy Paris, Author of Splitopia, DivORCEFORCE, https://www.divorceforce.com/ article/spotlight-wendy-paris-author-of-splitopia (last visited Apr. 28, 2018).

85. See. John H. Langbein, Destructive Federal Preemption of State Wealth Transfer Law in Beneficiary Designation Cases: Hillman Doubles Down on Egelhoff, 67 VAND. L. REV. 1665, 1669 (2014) ("This divorce revocation rule originated in the law of wills and was extended to financialaccount beneficiary designations as their use spread. What motivates the rule is the understanding that divorce commonly entails a sufficiently traumatic breach in the relations of the former spouses that they are not likely thereafter to intend to benefit each other by means of wealth transfer on death.”).

86. E.g., Murphy \& Singer, supra note 9 (discussing this change); Jana Singer, Dispute Resolution and the Postdivorce Family: Implications of a Paradigm Shift, 47 FAM. CT. REV. 363, 363-65 (2009).

87. Amy Ziettlow is a Pastor in the Evangelical Lutheran Church in America. Rev. Amy Ziettlow, HuFFPOST, https://www.huffingtonpost.com/author/rev-amy-ziettlow (last visited Jan. 28, 2018).

88. Amy Ziettlow \& NAOMi CAhn, Homeward Bound: Modern FAmilies, Elder Care, AND LOSS 11 2-13 (2017); see Naomi Cahn \& Amy Ziettlow, Inheritance and Divorce, INST. FOR FAM. STUD. (Sept. 6, 2016), https://ifstudies.org/blog/inheritance-and-divorce. 
supporting their joint children's caregiving to taking a much more active role. ${ }^{89}$

Beyond Homeward Bound, there has been relatively little research assessing society's perceptions regarding inheritance and obligation to family members after a divorce or remarriage. $9^{\circ}$ Sociologists Marilyn Coleman and Lawrence Ganong have suggested that divorce might not necessarily dissolve kinship ties. Ex-family members who continue to feel emotionally or interpersonally satisfied in their interactions with one another might still feel ongoing obligations of inheritance or care $9^{11}$ Coleman and Ganong designed a study to assess these attitudes about intergenerational obligations at a time of changing family structures. $9^{2}$ When they asked whether a former daughterin-law should be included in a will after a divorce, they found that one-quarter believed the former daughter-in-law should be included, especially if she remained in contact with her former father-in-law, while his son did not.93 Some of the open-ended responses suggested that the former daughter-in-law be excluded because, in the absence of a blood or marriage tie, she was not a member of the family. 94 Other responses defined family more broadly, and mentioned the former daughter-in-law's role in caring for a grandchild, as well as her closeness to the decedent; for example, one individual stated that "[i]f [the daughter-in-law] was always close to him, he could include her,

89. ZiETTLOW \& CAHN, supra note 89, at 34 ("[Will's mother] made meals for the brothers as well as for her ex-husband and delivered them each week. She sat vigil with her sons at the hospice inpatient unit at the hospital after their father lost consciousness and was near death. She also accompanied them to the funeral home and helped them pick out the casket and burial plot."). Cf. Marilyn Coleman \& Lawrence H. Ganong, Changing Families, Changing Responsibilities: FAmily Obligations Following Divorce AND REMARriage 3 (1999) (discussing the changes in the way family members view and care for each other after divorce).

9o. COLEMAN \& GANONG, supra note 89 , at 78 ; see Hirsch, supra note 1 , at $65^{\mathrm{O}-} 5^{1}$ (noting the studies and potential critiques, and suggesting that " $[\mathrm{t}]$ he Commissioners failed to mine this body of research-they did not do the leg work. Had they delved into the literature, it might have given them pause"). There is some research on related issues, such as attitudes toward stepparents' obligations to their stepchildren. See generally John C. Henretta et al., Parental Money Help to Children and Stepchildren, 35 J. FAM. ISSUES $113^{1}$ (2014) (identifying discrepancies between financial treatment of biological children and stepchildren); Miriam J. Maclean, Deirdre Drake \& Dianne Mckillop, Perceptions of Stepfathers' Obligations to Financially Support Stepchildren, 37 J. FAM. ECON. ISSUES 285 (2016) (examining public views on a stepfather's obligation to contribute financial on behalf of a stepchild). And another study found that adult children whose older parents remarried typically do not see their stepparents as family members. Lawrence Ganong \& Marilyn Coleman, Obligations to Stepparents Acquired in Later Life: Relationship Quality and Acuity of Needs, $61 \mathrm{~J}$. GERONTOLOGY: SERIES B 8o, 86 (2006).

91. See COLEMAN \& GANONG, supra note 89 , at 86 .

92. See generally Marilyn Coleman \& Lawrence H. Ganong, Attitudes Toward Inheritance Following Divorce and Remarriage, 19 J. FAM. \& ECON. ISSUES 289 (1998).

93. COLEMAN \& GANONG, supra note 89 , at 301 .

94. See id. at 303 . 
though normally that wouldn't be done."95 In research of actual relationships, studies have found that the length of the marriage affects the stepparent/stepchild relationship, and that divorced stepparents are likely to lose contact more quickly with their stepchildren than are widowed stepparents. $9^{6}$

Another survey focused on feelings of obligation if a family member needed either financial or caregiving help.97 The results revealed that respondents were more likely to favor their biological families over their stepfamilies. $9^{8}$ On the other hand, the numbers were comparatively close when it came to helping a grown child: $78 \%$ would feel obligated to help a grown biological child, and $62 \%$ would feel obligated to help a grown stepchild.99 Unfortunately, the study did not ask if those feelings would continue after the end of marriage to the stepparent. Nonetheless, the figures suggest a strong attachment between stepparents and stepchildren. This, attachment is reflected in the current version of the UPC; since 1990, in recognition of our "multiple-marriage society," the UPC has allowed a stepchild to inherit through intestacy if all other relevant relatives have predeceased. ${ }^{100}$

Adam Hirsch has also developed some empirical data on these issues. For example, he found that less than half $(37.9 \%)$ of divorcing spouses wished to leave nothing to their (almost ex-) spouses, meaning that close to two-thirds - even in the midst of divorce-did not want to disinherit entirely their former partners. ${ }^{101}$

95. Id. (emphasis added). The authors also note several limitations to the study, including that the population surveyed was primarily White and lived in one Midwestern state (Missouri). Id. at 292,312 .

96. See Claire M. Noël-Miller, Former Stepparents' Contact With Their Stepchildren After Midlife, 68 J. Gerontology: Series B 409, 414-15 (2013). See generally Daniela Klaus et al., Relationships to Stepfathers and Biological Fathers in Adulthood: Complementary, Substitutional, or Neglected?, 17 ADVANCES LIFE COURSE RES. 156 (2012) (finding that marital duration was associated with stronger stepfather/stepchild relationships); Adam Shapiro, Rethinking Marital Status: Partnership History and Intergenerational Relationships in American Families, 17 ADVANCES LIFE COURSE RES. 168 (2012) (exploring the impact of marital history on intrafamilial relationships).

97. A Portrait of Stepfamilies, Pew Res. Ctr.: Soc. \& Demographic Trends (Jan. 13, 2011 ), http://www.pewsocialtrends.org/2011/01/13/a-portrait-of-stepfamilies.

98. Id.

99. $I d$.

10o. UNIF. PROBATE CODE, prefatory note to 2010 amendment. (UNIF. LAW COMM'N 2010). As the UPC explained:

In the twenty or so years between the original promulgation of the Code and 1990, several developments occurred that prompted the systematic round of review .... $[\mathrm{T}]$ he advent of the multiple-marriage society, resulting in a significant fraction of the population being married more than once and having stepchildren and children by previous marriages ...."

Id.

101. Hirsch, Inheritance on the Fringes, supra note 23, at 259. 


\section{AdDItional POLICY ISSUES: GENDER, CLASS, AND RACE}

Revocation upon divorce statutes affect anyone who has written a will and people who have nonprobate assets who live in states with the broader statutes that cover nonprobate assets. Nonetheless, they also have disparate impacts, depending on gender, class, and race.

\section{Gender ${ }^{102}$}

Consider the gendered history of the divorce revocation statutes ${ }^{103}$ and who is most likely today to be disadvantaged by revocation upon divorce statutes. While the statutes today are gender neutral and serve to deny any surviving ex-spouse additional assets, not only are surviving ex-spouses more likely to be women, they are more likely older women who are economically weaker than their spouse, with fewer assets and less preparation for retirement. ${ }^{104}$ Indeed, there is a possible argument that revocation upon divorce disproportionately benefits men, as they disproportionately own the wealth in the family and they are, statistically, the first to die. ${ }^{105}$ Men are also four times more likely to live in a household with stepchildren than are women, ${ }^{106}$ so the impact of revoking ex-spouse designations upon divorce is more likely to affect a woman and her children than a man and his children.

102. Following the symposium at which this article was presented and during the editing process for this article, an important Supreme Court amicus brief raising some of these gender-related issues was filed by the Women's Law Project. Brief for The Women's Law Project et al. as Amici Curiae Supporting Respondent, Sveen v. Melin, No. 16-1432 (U.S. Feb. 28, 2018), 2018 WL 1156618.

103. See supra note 15 .

104. E.g., Ina Jaffe, For Women, Income Inequality Continues into Retirement, NPR (Nov. 17, 2015 , 5:46 AM), http://www.npr.org/2015/11/17/455888062/for-women-income-inequality-continuesinto-retirement; Christian E. Weller \& Michele E. Tolson, Women's Economic Risk Exposure and Savings, CTR. FOR AM. PROGRESS, (Apr. 27, 2017 , 9:05 AM), https://www.americanprogress.org/ issues/economy/reports/2017/o4/27/431228/womens-economic-risk-exposure-savings; see Paula A. Monopoli, Marriage, Property and [In]Equality: Remedying ERISA's Disparate Impact on Spousal Wealth, 119 YALE L.J. ONLINE 61, 63 (2009), https://www.yalelawjournal.org/forum/marriageproperty-and-inequality-remedying-erisas-disparate-impact-on-spousal-wealth ("Federal retirement and tax policy has effectively concentrated the power to control the family's financial future in the hands of one spouse.").

105. E.g., Shervin Assari, Why Do Women Live Longer than Men?, WorLd ECON. F. (Mar. 14, 2017), https://www.weforum.org/agenda/2017/o3/why-do-women-live-longer-thanmen (explaining that women's life expectancy is 81.2 years, while for men it is 76.4 ); CTRS. FOR Disease Control \& Prevention, U.S. DeP'T Health \& Human Servs., NaT'L Vital Statistics REP. NO. 65-O4, DEATHS: FINAL DATA FOR 2014, at 7 (2016), https://goo.gl/ajNgH4 (reporting a 4.8 year life expectancy difference between men and women in 2014). On the wealth gap, see generally Erez Aloni, The Marital Wealth Gap, 93 WASH. L. REV. 1 (2018). Of course, if women procrastinate more than men about estate planning, then it may be men who benefit; most of the cases, however, involve the surviving wife.

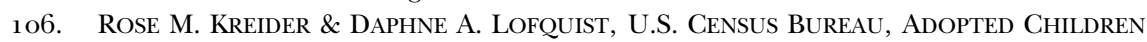
AND STEPCHILDREN: 2010, at 20 tbl.6 (2014), https://www.census.gov/prod/2014pubs/p2O572.pdf (showing that $1,354,977$ households have stepfathers and 339,369 have stepmothers). 
Furthermore, men are more likely to work, they have higher wages, and they accumulate more wealth. ${ }^{107}$ While the median wealth of married couples is much higher than that of single men and women, ${ }^{108}$ most of that wealth is accumulated by the husband; married women are paid less, have less in retirement savings, and typically work less. ${ }^{109}$ For example, women need to save almost twice as much as men to achieve parity in retirement accounts for three primary reasons: (1) women work fewer years; (2) women earn less than do men; and (3) women take few risks in investment, so they have lower returns on their investments. ${ }^{10}$ Furthermore, median wealth of single men is more than three times as high as the median wealth for single women. ${ }^{111}$ Single women even experience less appreciation in their homes than do men. ${ }^{112}$ This means that revocation upon divorce, while not intentionally discriminatory, has a disproportionately negative impact on ex-spouses who are women. Thus, it is not surprising that most of the reported cases which dispute revocation upon divorce involve women who have been named as beneficiaries and who seek to retain those benefits.

107. See, e.g., MARIKO Lin CHANG, SOCIOLOGISTS FOR WOMEN In SOC'Y, FACT SHEET: WOMEN AND WEALTH IN THE UNITED STATES 2-3 (2010), https://www.socwomen.org/wp-content/uploads/ 2010/05/fact_2-2010-wealth.pdf; CHRISTIANNE CORBETT \& CATHERINE HiLl, AM. ASSOC. OF UnIV.

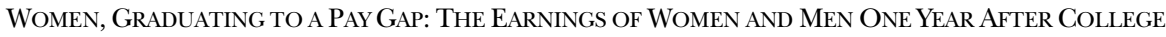
GRADUATION 5, 2O-21 (2012), http://www.aauw.org/files/2013/o2/graduating-to-a-pay-gap-theearnings-of-women-and-men-one-year-after-college-graduation.pdf.

108. MARIKo CHANG, ASSET Funders NeTWORK, WOMEN AND WEALTH: INSights FOR GRANTMAKERS 5 (2015), http://www.mariko-chang.com/AFN_Women_and_Wealth_Brief_ 2015.pdf; see Jennifer Barrett, What's Worse Than the Gender Wage Gap? The Wealth Gap, CNBC (Sept. 3, 2015, 9:59 AM), http://www.cnbc.com/2015/o9/o3/whats-worse-than-the-genderwage-gap-the-wealth-gap.html.

109. See generally U.S. DEP'T OF LABOR, WOMEN AND RETIREMENT SAVINGS (2017), https:// www.dol.gov/sites/default/files/ebsa/about-ebsa/our-activities/resource-center/publications/ women-and-retirement-savings.pdf (showing that women tend to invest less in retirement savings plans); Claudia Goldin et al., The Expanding Gender Earnings Gap: Evidence from the LEHD-2Ooo Census, 107 AM. ECON. REV. 110 (2017) (analyzing earnings disparity between men and women); Diane Garnick, Why Aren't Women Saving Enough for Retirement?, YALE INSIGHTS (May 1, 2017), http:/ /insights.som.yale.edu/insights/why-aren-t-women-saving-enough-for-retirement (explaining that women tend to not save as much through a retirement savings plan); Anya Kamenetz, How Women Should Approach Retirement, CHI. TRIB. (Jan. 24, 2017, 10:30 PM), http:// www.chicagotribune.com/business/sns-201701 241900-tms-savingsgctnzy-a201701 24-20170 124-story.html (explaining that women tend to invest less in retirement savings plans because they tend to earn less, spend more time outside of the home, and raise single parent families).

1 10. DiANE GARNick, TIAA, INCOME INSIGHTS: GENDER RETIREMENT GAP 2 (2016), https://www.tiaa.org/public/pdf/income_gender.pdf; LESLIE E. PAPKE, LINA WALKER, AND Michael Dworsky, Retirement Security for Women: Progress to DATe and Policies for TOMORROW 1 (2016), https://www.brookings.edu/wp-content/uploads/2016/o7/o3_retirement women.pdf.

111. Chang, supra note 103, at 5. Erez Aloni finds a smaller gap at death. See Aloni, supra note 105 .

1 12. Martha C. White, Gender Pay Gap Leads to Wealth Gap in the Housing Market, NBC NEWS (May 26, 2016, 3:00 PM), https://www.nbcnews.com/better/money/gender-pay-gap-leadswealth-gap-housing-market-n 581046 . 
Dean Laura Rosenbury suggests that one way to view the federal preemption cases is as "further[ing] the neoliberal interest in privatizing the dependencies of family members," ${ }^{113}$ generally women and children. ${ }^{114}$ That seems accurate as a description of much of family law itself, but in probate law, this may actually reflect administrative efficiency rather than substantive policy. At the same time, the federal preemption cases serve-albeit probably not intentionally - as a recognition of the bonds that caused the decedent to name the beneficiary in the first place, acknowledgement that marriages may end, but the relationship may continue. The name of the beneficiary may reflect ongoing bonds-or it may reflect that the decedent assumed revocation upon divorce, did not know how to change the beneficiary, or simply procrastinated. ${ }^{115}$

\section{Class}

Trusts and estates practitioners primarily serve wealthier individuals, and the development of much of trusts and estates doctrine has focused on that group of clients. ${ }^{116}$ People who have engaged in the type of estate planning that is most likely to result in a will are older, wealthier, and more highly educated; $55 \%$ of Americans whose household income is $\$ 75$, ooo or more have wills, while only $31 \%$ of those below $\$ 30$,ooo have one. ${ }^{117}$ And almost double-61\%—of those with a postgraduate education have a will compared to those with a high school education or less. ${ }^{118}$ The statistics do not give us information on whether those people with a will have updated their estate plans following a major life event, but given that they are more likely to have a will in the first place, they are probably more likely to update estate planning documents after a divorce. Indeed, they are probably more likely to have a lawyer at divorce. Consequently, there may be, as John Langbein predicts, a

113. Rosenbury, supra note 2, at 1869 ("In particular, both Egelhoff and Hillman suggest that the legal status of marriage should entail lifelong support unless a spouse takes affirmative steps to end both the legal relationship and all provisions for support made during the relationship. In other words, divorce is not enough to sever the support function . . ..”).

1 14. See, e.g., Deborah Dinner, Strange Bedfellows at Work: Neomaternalism in the Making of Sex Discrimination Law, 91 WASH. U. L. REV. 453, 522-23 (2014) (discussing how legislation and the courts in California, at times, seem to rely on sexual stereotypes); Laura A. Rosenbury, Friends with Benefits?, $106 \mathrm{MICH}$. L. REV. 189, 226 (2007) (discussing the prioritization of "domestic relationships over other relationships"). Consider that Ariela Dubler argues that judges in the late nineteenth century used the doctrine of common law marriage to privatize dependence. Ariela R. Dubler, Note, Governing Through Contract: Common Law Marriage in the Nineteenth Century, 107 YALE L.J. $1885,1886-87$ (1998).

115. See Jeff Reeves, Plan Ahead: $64 \%$ of Americans Don't Have a Will, USA ToDAY (July 11 , 2015, 1:30 PM), https://www.usatoday.com/story/money/personalfinance/2015/07/1 1/estateplan-will/ 71270548 .

116. See, e.g., Boni-Saenz, supra note 38, at 17-18 (making a similar critique).

117. Jeffrey M. Jones, Majority in U.S. Do Not Have a Will, Gallup News (May 18, 2016), http://www.gallup.com/poll/191651/majority-not.aspx.

118 . Id. 
class effect. ${ }^{119}$ If lower income decedents are less likely to have updated their spousal beneficiary designations, then the divorce revocation for nonprobate assets is more likely to benefit them; if the wealthy are more likely to have wills, then divorce revocation for probate documents is more likely to benefit them.

However, the data in support of any class effect are equivocal. Consider that the wealthier, more highly educated group may be more likely to have the types of governing documents that would be affected by a divorce. For example, in the bottom quarter of the civilian wage scale, only $24 \%$ of employees participate in a retirement benefit plan of some sort; among those in the top quarter, $79 \%$ participate. ${ }^{120}$ Moreover, marriage rates are higher for wealthier individuals, ${ }^{121}$ so they are more likely to face issues concerning spousal designations. Conversely, low-income couples are more likely to divorce. ${ }^{122}$

Because of the complexity of these statistics-low income people have higher divorce rates but lower rates of marriage and lower rates of accumulating assets and writing wills-the class impact of revocation upon divorce statistics is difficult to evaluate. The revocation statutes could affect lower income people more if the statutes revoke nonprobate assets because lower income people might be less likely to receive advice on the need to changes beneficiary designations. Joint assets would presumably be divided on divorce, but retirement plans and insurance would use beneficiary designations, which people often forget to change. ${ }^{123}$ In situations where a decedent dies without a will and with only probate assets (or no assets at all), then the statutes would have no effect because the laws of intestacy function like a revocation statute to disinherit the former spouse. In the alternative, the statutes may be somewhat more likely to benefit higher income couples, in part because wealthy people are more likely to have higher rates of ownership of both probate and nonprobate assets. ${ }^{124}$

1 19. Langbein, supra note 85, at 1668-69 ("Thus, these cases of stale spousal beneficiary designations arise mostly among persons of modest means-persons who, when they divorce, do not find their way to expert counsel, or indeed, to any counsel.").

1 20. BUREAU OF LABOR STATISTICS, DEP'T OF LABOR, TABLE 2. RETIREMENT BENEFITS: ACCESS, PARTICIPATION, AND TAKE-UP RATES, CiVIliAN WORKERS, MARCH 2016 (2016), https:// www.bls.gov/ncs/ebs/benefits/2016/ownership/civilian/tableo2a.pdf (last visited Apr. 27, 2018).

121. See Kim Parker \& Renee Stepler, As U.S. Marriage Rate Hovers at $50 \%$, Education Gap in Marital Status Widens, PEW RES. CTR.: FACT TANK (Sep. 14, 2017), http://www.pewresearch.org/ fact-tank $/ 2017 / 09 / 14 /$ as-u-s-marriage-rate-hovers-at-5o-education-gap-in-marital-status-widens; see generally JUNE CARBONE \& NAOMI CAHN, MARRIAGE MARKETS: HOW INEQUALITY IS REMAKING THE AMERICAN FAMILY (2014) (discussing the impact of inequality on marriage, including divergence in marriage rates by educational attainment).

122. See CARBONE \& CAHN, supra note 121 , at $15^{-16}$.

123. See Sterk \& Leslie, supra note 5 , at $177-78$.

124. See Lisa J. Dettling et al., Recent Trends in Wealth-Holding by Race and Ethnicity: Evidence from the Survey of Consumer Finances, BOARD OF GOVERNORS OF THE FED. RES. SYS. (Sept. 27, 2017), https://doi.org/10.17016/2380-7172.2083. 


\section{Race}

The income and wealth gap not only has class effects, but also has racial consequences. Wealth in the United States varies by race. ${ }^{125}$ For example, White households had 13 times the median wealth of Black households in 2013, and ten times the median wealth of Hispanic households. ${ }^{126}$ This racial wealth gap impacts long-term planning. Blacks who have comparable incomes to Whites are less likely to own a home. ${ }^{127}$ And those who own a home and who are employed are more likely to purchase life insurance. ${ }^{128}$ Blacks and Hispanics have substantially lower amounts in retirement savings than do whites, ${ }^{129}$ and they are much less likely to have a will. ${ }^{13^{\circ}}$ The statutes may thus be somewhat less likely to affect them, although that may be derivative of their socioeconomic status.

These gender, class, and race disparities ever present in today's society, should, at the very least, initiate the need for reflection on the repercussions of revocation upon divorce statutes. While revocation upon divorce statutes are based on presumptions concerning the decedent's intent, that presumption is not based on strong empirical evidence. Moreover, the rule

125. E.g., Laura Sullivan Et al., The Racial Wealth GaP: Why Policy Matters 7 (2016), http://www.demos.org/sites/default/files/publications/RacialWealthGap_2.pdf; Dettling, supra note 125 .

126. Rakesh Kochhar \& Richard Fry, Wealth Inequality has Widened Along Racial,Eethnic Lines Since End of Great Recession, PEW RES. CTR. (Dec. 12, 2014), http://www.pewresearch.org/facttank/2014/12/12/racial-wealth-gaps-great-recession. Asian Americans present a more complex story, with both higher family incomes and higher poverty rates. CHRISTIAN E. WELLER \& JEFFREY P. THOMPSON, CTR. FOR AM. PROGRESS, WEALTH INEQUALITY AMONG ASIAN AMERICANS GREATER THAN AMONG WHITES 3 (2016), https://cdn.americanprogress.org/content/uploads/2016/12/

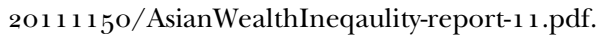

127. "The homeownership rate of upper-income blacks $(68 \%)$ is significantly lower than the rate of upper-income whites $(84 \%)$. The same is true among the highly educated $-58 \%$ of black householders with a college degree own their home, compared with $76 \%$ of whites." PEW RES. Ctr., On Views of RACE AND INEQUALITY, Blacks AND WHITES ARE WORLDS APART 25 (2016) (citations omitted), http://assets.pewresearch.org/wp-content/uploads/sites/3/2016/o6/ST_ 2016.06.27_Race-Inequality-Final.pdf.

128. See Timothy F. Harris \& Aaron Yelowitz, Racial Disparities in Life Insurance Coverage, 5 o APPLIED ECON. 94, 100 (2018). The authors find that Black households are more likely to own life insurance compared to those in the same demographics. Id. See Tim Grant, Why AfricanAmericans are So Loyal to Life Insurance, PitTsBurgh Post-GazetTe (Aug. 14, 201 1, 3:00 AM), http://www.post-gazette.com/business/businessnews/201 1/o8/14/Why-African-Americans-are-soloyal-to-life-insurance ("African-Americans continue to embrace life insurance more than people of other races and ethnicities.”).

1 29. NARI RHEE, NAT'L INST. ON RET. SEC., RACE AND RETIREMENT INSECURITY IN THE UNITED STATES 10-13 (2013), https://www.giaging.org/documents/NIRS_Report_12-10-13.pdf.

13o. A.L. Kennedy, Statistics on Last Wills $\mathcal{E}$ Testaments, LEGALZOOM, http:// info.legalzoom.com/statistics-last-wills-testaments-3947.html (last visited Apr. 27, 2018). Because the statistics are so imprecise, it is unclear whether the racial disproportionality is due to income or race. That is, lower incomes of all races/ethnicities may face similar conditions, but there may also be circumstances particular to high income Blacks and Hispanics, such as differing marriage and divorce rates. 
has a broad application that, at least in some cases, undercuts the decedent's intent.

\section{APPROACHES OF OTHER COUNTRIES}

Other countries take a variety of approaches to the impact a marriage, civil partnership, ${ }^{131}$ or divorce has on a will or bequests to an ex-spouse and relatives of the ex-spouse, and whether the revocation extends to nonprobate instruments. In a number of jurisdictions, marriage still revokes the testator's premarital will, unless a contrary intention appears. ${ }^{13^{2}}$ There is a slow and halting trend toward an approach that divorce revokes various types of designations, but many jurisdictions ${ }^{133}$ continue to adhere to a system in which divorce has no effect. The lack of uniformity suggests that there is not one right approach to the issue.

In some jurisdictions, there is no presumption concerning a will's revocation upon divorce. The list includes both common law and civil law countries: Liechtenstein, France, Belgium, Poland, Spain, Thailand, Cyprus, China, Ireland, Japan, Panama, and Canada (Newfoundland and Labrador, Northwest Territories, New Brunswick, Nunavut). ${ }^{134}$ In other jurisdictions, an entire will might be revoked, unless the testator shows a contrary intent. ${ }^{135}$ In jurisdictions that presume revocation, some include only wills; ${ }^{13}{ }^{6}$ others extend the presumption to nonprobate instruments. In Sweden, the presumption is particularly broad because revocation is presumed once divorce proceedings start and a final divorce is not necessary. ${ }^{137}$

131. England and Wales, for example, give civil partnerships the same effect as marriage. INTERNATIONAL SUCCESSION 257 (Louis Garb \& John Wood eds., 4th ed. 2015); $c f$. Jessica Elgot, Most Same-Sex Marriages in England and Wales Began as Civil Partnerships, GUARDIAN (Jan. 13, 2016, 12:51 PM), https://www.theguardian.com/society/2016/jan/13/most-same-sex-marriages-englandwales-already-civil-partnerships.

132. For example, England and Wales, Australia, New Zealand, Cyprus, Ireland, Canada (Manitoba, Newfoundland and Labrador, Northwest Territories, New Brunswick, Nova Scotia, Nunavut, Ontario, Prince Edward Island, Saskatchewan). See generally INTERNATIONAL SUCCESSION, supra note 126 (analyzing the rules of succession in jurisdictions around the world).

133. I refer to "jurisdictions" rather than countries because, for example, in Canada and Australia the provinces and states and territories take different approaches.

134. See infra text accompanying notes 130, 134-39. For more information, see generally INTERNATIONAL SUCCESSION, supra note 126 (discussing how various countries treat wills upon divorce). For Newfoundland and Labrador, see Province of Newfoundland \& Labrador Wills Act, R.S.N.L. 1990, c W-10 (Can.). As one Irish solicitor advises, based on a presumption about the divorced testator, "The best advice is to make an entirely new Will without delay." FAQ, BROWNE \& MURPHY SOLICS., http:/ /www.bmsolicitors.ie/wills-and-probate/faqs (last visited Apr. 27, 2018).

135. INTERNATIONAL SUCCESSION, supra note 126 , at 25 (discussing will revocation in Western Australia); see Simon Creek, Australia: The Effect of Marriage or Divorce on Wills in WA, MONDAQ, http://www.mondaq.com/australia/x/46881o/wills+intestacy+estate+planning/The+ effect+of+marriage+or+divorce+on+wills+in+WA (last updated Feb. 24, 2016).

136. INTERNATIONAL SUCCESSION, supra note 111, at 257 (discussing will revocation in England and Wales).

137. See id. at 792; see ÄRVDABALK (1958:637) (Swed.). 
In Ontario, for example, a statute enacted in 1980 provided that divorce revokes any bequest to a former spouse unless "a contrary intention appears by the will." ${ }_{138}^{8}$ In a 1986 Ontario case, Gertrude Alva Billard claimed her exhusband's bequest to her had not been revoked by their divorce.139 The parties had separated in May 1979 and signed a separation agreement the next month. ${ }^{14^{\circ}}$ The testator executed his will in September 1979, which provided: "If my spouse GERTRUDE ALVA BILLARD survives me [then my executor shall] pay or transfer $10 \%$ of the residue of my estate to her for her own use absolutely ...."141 The court held it could not consider the surrounding circumstances-that the will was executed subsequent to the separation agreement-and found that the requisite contrary intention did not appear on the face of the will. ${ }^{14^{2}}$ While the court conceded that it might have concluded that the surrounding circumstances did show a contrary intention, it noted that it was constrained from doing so by the words of the statute. ${ }^{143}$

In contrast to the strong presumption applicable to probate assets, and in a reversal of former legislation, there is no presumption applicable to nonprobate designations in Ontario. ${ }^{144}$

138. Succession Law Reform Act, R.S.O. 1990, c. S.26, s. 17 (2) (Can. Ont.); In re Billard, 1986 CarswellOnt 329, para. 3 (Can. Ont. H.C.J) (WL); The Meaning of "Contrary Intention Appears by the Will”, in 22 EsTATES \& TRUSTS RePORTS $15^{1,1} 5^{1}$ (T.G. Youdan et al. eds., 1987).

139. In re Billard, 1986 CarswellOnt 329, para. 4 (Can. Ont. H.C.J) (WL).

140. Id. at para. 2.

141. Id. at para. $2-3$.

142. See id. at para. 5 .

143. See id. "If it were open to me to find, on the balance of probabilities, from the making of the will and all the surrounding circumstances, that a 'contrary intention' was shown, I might do so." Id. at para. 6.

144. See Richardson Estate v. Mew, 2009 CarswellOnt 2576, para. 61 (Can. Ont. C.A.) (WL); Charles Wagner, Should Divorce Revoke the Beneficiary Designation in an Insurance Policy?, WAGNER SIDLOFSKY LLP (July 26, 2015), http://www.wagnersidlofsky.com/should-divorce-revoke-thebeneficiary-designation-in-an-insurance-policy. 
In South Africa, revocation upon divorce is effective only for three months after the divorce. ${ }^{145}$ In Western Australia, the entire will is revoked upon divorce, unless there is contrary evidence in the will. ${ }^{14}$

Scotland was a country without revocation-upon-divorce presumptions until 2015 , when legislation was introduced based " $[\mathrm{o}] \mathrm{n}$ the assumption that a testator would not want an ex-spouse or ex-civil partner to inherit ...[L]eav[ing] the current law unchanged ... would not meet the aim of modernising the law to reflect the expectations of $21^{\text {st }}$ century Scotland." ${ }^{4} 4$ The new legislation has an exception for when the will contains an express provision that the former spouse will continue to be a beneficiary or fiduciary "even if the marriage or civil partnership is terminated." ${ }^{4} 8$ The revocation explicitly does not, however, affect the appointment of a former spouse or civil partner as a guardian to minor children pursuant to the will. ${ }^{149}$

As mentioned, a number of jurisdictions apply their revocation presumptions to nonmarital couples. ${ }^{15^{\circ}}$ The jurisdictions that have moved toward revocation-upon divorce assume that this revision is in line with the wishes of most decedents. And that is the fundamental issue with which all such jurisdictions must struggle: just what did the decedent intend.

145. Wills Act 7 of $1953 \S 2$ B (S. Afr.) (amended 1992). As the court explains:

The Wills Act stipulates that, except where you expressly provide otherwise, a bequest to your divorced spouse will be deemed revoked if you die within three months of the divorce. This provision is to allow a divorced person a period of three months to amend his/her will, after the trauma of a divorce. Should you, however, fail to amend your will within three months after your divorce, the deemed revocation rule will fall away, and your divorced spouse will benefit as indicated in the will.

DeP'T OF Justice \& Constitutional DeV., The Master of THe High Court Frequently Asked QUESTIONS 9 (2011) (S. Afr.), http://www.justice.gov.za/master/m_pamphlets/2011 moh_ faq $\% 20 A_{5}$.pdf. I am indebted to Adam Hirsch for this reference.

146. Wills Amendment Act 2007 (W. Austl.) \$ 14A (Austl.), https://www.slp.wa.gov.au/pco/ prod/filestore.nsf/FileURL/mrdoc_5723.pdf/\$FILE/Wills\%2oAmendment\%2oAct\%202007 $\%_{20} \%_{20} \%_{5}$ Boo-Oo-O $\%_{5}$ D.pdf.

147. Succession (Scotland) Bill 2015, Policy Memorandum If 16, 19 (Scot.), http:// www.parliament.scot/S4_Bills/Succession\%20(Scotland) \% 20Bill/b75s4-introd-pm.pdf. Indeed, of the 10 comments received, all but one were in favor of this approach. Id. II 17 .

148. Succession (Scotland) Act 2016, (ASP 7) § 1, Il 3. http://www.legislation.gov.uk/asp/ $2016 / 7 /$ section/1/enacted. A civil partnership is a legally-established union.

149. Leigh Beirne, New Rules on Succession in Scotland - How They Will Affect Who Inherits Your Estate, HARPER MACLEOD LLP (Mar. 11, 2016), https://www.harpermacleod.co.uk/hminsights / 2016/march/new-rules-on-succession-in-scotland-how-they-will-affect-who-inherits-your-estate; Amanda Davy, What The Succession (Scotland) Act 20 I 6 May Mean For You, Burness PAull: BLOG (Jan. 9, 2017), http://www.burnesspaull.com/blog/2017/o1/what-succession-scotland-act-2016may-mean-you.

150. E.g., Manitoba includes "common-law partnerships." The Wills Act, R.S.M. 1988, c. $\mathrm{W}_{1} 5^{\mathrm{O}}$, SS. $17,18,18(4)$ (Can.) (common law relationships). Section 1 defines "common law".

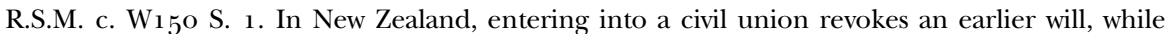
dissolving the civil union revokes provisions in favor of the former partner. See Wills Act 2007 ss 17 subss (1) (c) 19 (N.Z.), http://www.legislation.govt.nz/act/public/2007/oo36/latest/whole.html. 


\section{MOVING FORWARD}

It is clear that revocation-upon-divorce statutes can be helpful to the forgetful or uninformed ${ }^{15^{1}}$ decedent in many situations. Moreover, if divorce really does represent a clean break, then probate laws' presumptions are in line with the direction of modern family law. Yet it is also clear that the revocation presumption may undermine the decedent's intent in other situations. Here again, looking to family law, ex-spouses often remain connected formally through custody provisions for their children or pension division, or more formally through friendship, and they may have deliberately sought a more collaborative divorce to foster harmonious post-divorce relationships.

The pragmatic problems with the revocation statutes fall into two different areas: (1) they may be overbroad, sweeping in situations where there was no intent to revoke a beneficiary designation; and (2) they may be too narrow, not covering all situations, such as those involving separation or nonmarital partners. ${ }^{15^{2}}$ At the policy level, the statutes are at the intersection of potentially conflicting goals: Respecting marital wealth accumulation and the clean break of divorce; honoring the testator's intent; requiring companymandated procedures for nonprobate assets; encouraging bonds in divorced families; increasing ease of administration; and privatizing elder care. Even more fundamentally, as is true for so many other issues in trusts and estates law, there are critical questions on the role of formality v. function $v$. efficiency. ${ }^{153}$ What remains is the question of what to do. How are legislatures and courts to balance presumed intent, actual intent, and the various policy goals?

The contextual background (i.e., understanding the differing theoretical and pragmatic considerations) provides the basis for moving forward in developing potential solutions to this challenge. This section addresses several potential reforms that respond to this question. The solutions within probate law fall along two distinct axes. One axis concerns the applicability of the presumption, with reversing the presumption-or abolishing it altogetherat one end and strengthening the presumption at the opposite end. The other axis concerns whether any such presumptions should apply only to married

151. They may reasonably assume that the divorce itself effectuates the revocation of all financial benefits, or they might have relied on the divorce lawyer-if they had one-to inform them of any necessary changes to financial documents. Setting aside privity issues, a disappointed beneficiary might use malpractice, claiming that the divorce lawyer should have told the decedent about the need to reinstate the ex-spouse as a beneficiary after the divorce, if there is evidence of what the decedent wanted. See Lucas v. Hamm, 364 P.2d 685, 690 (Cal. 1961) (en banc) (stating that the lawyer should have drafted around the Rule Against Perpetuities).

152. See Sterk \& Leslie, supra note 5 , at $18_{3}$ (addressing this issue in the pre-Obergefell context, when not all states recognized marriages between same-sex partners).

153. See generally Boni-Saenz, supra note 38 (critiquing the impact of formalism on donative errors and need for reform of inheritance law-based inequalities). 
couples or should be extended to nonmarital partners. Another set of reforms addresses changes outside of probate law.

My overall goals in exploring these reforms are, first, to develop a more functional approach that would acknowledge caregiving and functional familial relationships, ${ }^{154}$ and second, to respect donative intent.

\section{A. THE PRESUMPTION ITSELF}

The reforms of revocation-upon-divorce statutes along this first axis-just what should be presumed upon relationship dissolution-could take a number of different forms. First, the presumption itself could change: It might be abolished altogether or become irrebuttable. Second, the existing presumption could be more easily rebutted; for example, in interpreting whether revocation is intended, courts could consider surrounding circumstances. ${ }^{155}$ Along the second axis, which examines coverage of any presumption, the presumption could be extended to nonmarital partners and date to the filing of a divorce petition; that is, based on a showing of an intimate relationship between the testator/owner and the beneficiary, any devise or beneficiary designation would be subject to the same presumptions as for a divorced couple, and the presumption would extend to the initial court filing.

\section{Abolishing the Presumption}

Revoking the current presumption would have a number of benefits. First, it would prevent further conflict between state and federal laws ${ }^{15} 5^{6}$ on the applicability of the presumption. As numerous other trusts and estates scholars have noted, there is a movement to unify the laws of probate and nonprobate transfers. ${ }^{157}$ Abolishing the presumption would be one way of

154. For a brief discussion of this approach, see Susan N. Gary, Adapting Intestacy Laws to Changing Families, 18 LAW \& INEQ.: J. THEORY \& PRAC. 1, 71-73 (2000) (arguing that courts should have discretion to find a functional parent-child relationship); Lee-ford Tritt, Sperms and Estates: An Unadulterated Functionally Based Approach to Parent-Child Property Succession, 62 SMU L. REV. 367 , 373 (2009) (defending a functional approach to defining a parent-child relationships); BoniSaenz, supra note 38 , at 44-45; Spitko, supra note 27 , at $25^{8}$ (advocating for inclusion of committed unmarried partners in intestacy codes). See also Frances H. Foster, The Family Paradigm of Inheritance Law, 8o N.C. L. REV. 199, 248, 256-57 (2001) (critiquing intestacy laws on the grounds that they do not recognize caregiving relationships that are not based on blood, adoption, or marriage).

155. See A. SEan Graham, Hull \& Hull LlP, Evidence in Estate Litigation and What to WATCH FOR AS THE DRAFTING SOLICITOR: KeY ISSUES AND UPDATE 10-11 (2008); Campbell v. Shamata, 2002 CarswellOnt 58 , para. 7 (Can. Ont. S.C.J.) (WL) (stating that "a consideration of surrounding circumstances may be necessary to properly interpret the will an dgive [sic] effect of the wishes of the testator . . the so-called 'armchair rule"”).

$15^{6}$. See supra notes $35^{-37}$ and accompanying text (discussing preemption).

157. E.g., Langbein, supra note 85 , at 1667-68; Waggoner, supra note 24, at 1642 ; see Thomas P. Gallanis, The U.S. Supreme Court and the Law of Trusts and Estates: A Law Reformer's Perspective, 
doing so and it would serve to unify federal and state law approaches. ${ }^{15}$ Second, no presumption could simplify the disposition of the decedent's probate and nonprobate assets: there would be no need to go beyond the words in the document. This would respect the formalism involved in estate planning. ${ }^{159}$ Third, and lastly, estate planners would have an easy workaround; wills would be drafted with bequests to "my current spouse." This might also prompt companies that offer nonprobate assets to remind purchasers of the need to update their beneficiary designations, a measure that could help in avoiding any potential litigation at the death of the policyholder. ${ }^{160}$

Changing the law is not, of course, so easy. Revocation-upon-divorce has become increasingly entrenched, and there is sufficient uncertainty as to the probable intent of a divorced decedent that it is difficult to know whether a presumption for or against revocation is warranted. Perhaps one place to start would be to eliminate the presumption with respect to the ex-spouse's family members, where there is considerable uncertainty as to whether divorce severs these additional ties. ${ }^{161}$

\section{Making the Presumption Irrevocable}

Many courts already treat the current presumption as essentially irrevocable, so legislating such a presumption would be relatively easy to administer. It would not, however, resolve the conflict between state and federal laws ${ }^{162}$ on the applicability of the presumption, however, unless Congress similarly amended the relevant federal legislation. Congress could either explicitly defer to state law or incorporate an irrevocable presumption itself. Finally, estate planners would continue to have an easy work-around; they could advise their clients to change the beneficiary designations postdivorce.

\section{Rebutting the Current Presumption}

A more promising possible reform is based on retaining the current presumption, in at least some form, and addressing the means for rebutting

\footnotetext{
42 AM. C. TR. \& EST. Couns. L.J. 1 1, 13 (2016) (noting that the Supreme Court's preemption cases are "[c]omplicating the project of default-rule unification").

158 . Of course, the UPC has chosen the opposite approach to unify probate and nonprobate assets, but Congress has not made that choice, creating the oft-litigated divergence between state and federal laws. See, e.g., Gallanis, supra note $15^{2}$, at 13 ; Langbein, supra note 85 , at $1667-68$; Waggoner, supra note 24 , at 1642 .

159. See David Horton, Tomorrow's Inheritance: The Frontiers of Estate Planning Formalism, 58 B.C. L. REV. 539, 558-59 (2017).

16o. See Sterk \& Leslie, supra note 5; see also infra note 173 and accompanying text (discussing a company's desire to have holders update their list of beneficiaries).

161. See Hirsch, supra note 1 , at $648-5$ o.

162. See supra notes $2,35^{-37}$ and accompanying text (discussing preemption).
} 
it. ${ }^{163}$ Although the existing UPC allows for rebuttal, courts have rarely permitted it. ${ }^{164}$ To achieve this end, courts might provide a more liberal interpretation to the statutory language or legislatures might provide additional means of rebuttal.

\section{i. $\quad$ Reinterpreting Existing Language}

As noted earlier, the presumption can only be rebutted by the express terms of a governing instrument, a court order, or some type of marital agreement concerning the spouses' property. ${ }^{16_{5}}$ If the decedent changed a beneficiary designation post-divorce, for example, then that would satisfy the first exception; ${ }^{166}$ a court order explicitly granting a particular asset (such as a retirement account) to the beneficiary would satisfy the second; ${ }^{167}$ and an explicit provision in a marital agreement designating a beneficiary would satisfy the third. ${ }^{168}$ The purpose of these rebuttals is on the testator's intent to opt out of the presumption through some type of formal writing.

Courts that have considered whether an unchanged beneficiary designation satisfies the first exception have decided there must be something other than a failure to change the beneficiary, and, as noted earlier, they do not apply the harmless error rule. ${ }^{169}$

One potential approach would be to distinguish between designations of "my spouse, Blaine" and "Blaine," with the former revoked because Blaine is referred to by relationship ("my spouse"), and the latter not revoked, because Blaine is referred to as an individual, without information on Blaine's relationship to the decedent. This seems an overly technical means of resolving the problem, and courts have-appropriately-not used this as a basis for revoking the presumption. ${ }^{170}$

163. To be sure, this would not resolve the federal/state preemption issue, which would still require Congressional action. See supra notes 2, 35-37 and accompanying text.

164. See supra notes $63^{-6} 4$ and accompanying text (discussing rebutting the presumption); supra Section II.D.

165. See supra Section I.D.

166. For example, when Washington State considered a divorce revocation statute, "legislators were informed that . . . a divorced testator could give a former spouse a gift under his or her will only by executing a new will following the divorce." Mearns v. Scharbach, 12 P.3d 1048, 1053 (Wash. Ct. App. 2000); cf. Primerica Life Ins. Co. v. Madison, 57 P.3d 1174, $1176-78$ (Wash. Ct. App. 2002) (holding that where a divorced husband had an insurance rider on his ex-wife, divorce did not revoke rider).

167. Because many separation/divorce agreements are incorporated or merged into court orders (some are not), that situation would also seem to satisfy this exception.

168. See UNIF. Probate CODE $\$$ 2-804 (b) (UNIF. LAW ComM’N 2010).

169. See In re Estate of Lamparella, 109 P.3d 959, 965-67 (Ariz. Ct. App. 2005); Buchholz v. Storsve, 740 N.W.2d 107, $110-11$ (S.D. 2007).

170. See Nichols v. Baer ex rel. Suiter, 78 A.3d 344, 350-54 (Md. 2013); Langston v. Langston, 266 S.W.3d 716, 721-22 (Ark. 2007); see also Hirsch, Inheritance on the Fringes, supra note 23, at $25^{1} \& \mathrm{n} .87$ (indicating other cases where courts have treated generic descriptions of beneficiaries as surplusage). 


\section{ii. Additional Language}

An alternative might be to add commentary, or even statutory text, permitting rebuttal based on a showing of "probable intent." Additional modifications, suggested by international law, would be narrowing the revocation so that it did not include designations of an ex-spouse as the guardian of a minor child or so that it was limited in time. The Uniform Law Commission might undertake such revisions, or states could amend existing statutes.

\section{a. Showing Probable Intent}

As with other aspects of interpreting wills and construing intent, extrinsic evidence that goes beyond the face of the will would be permitted where there is clear and convincing evidence of the testator's intent. ${ }^{171}$ Furthermore, and unlike the Western Australia wills law, this solution would allow the evidence could go beyond the face of the will. ${ }^{172}$

The revised statutory language might simply add a new provision for probable intent, such as California's- " $[\mathrm{t}]$ here is clear and convincing evidence that the transferor intended to preserve the . . . transfer to the former spouse" ${ }^{173}$ - or it could list factors to be considered. As Adam Hirsch has suggested, such factors might include the post-divorce relationship between the ex-spouses and the length of time between divorce and death. ${ }^{174}$ Courts might also include oral statements of intent. ${ }^{175}$ If the decedent had remarried, then this might also show intent to revoke. In addition, the existence of a marital agreement explicitly addressing nonprobate assets could serve as conclusive proof that the presumption should be applied.

Showing probable intent through surrounding circumstances is consistent with the movement more generally in trusts and estates law to allow for extrinsic evidence even when the words of the document are clear. As is true for the harmless error standard, a clear and convincing evidence standard would provide some protection for potential heirs against unlimited

171. See generally Gary, supra note 63 (explaining the discretion needed for interpreting a will based on both the face of the will and the testator's intent). As Professor Gary suggested in the context of intestacy rules, if information about the testator's actual intent is known, why not use it?

172. See Wills Amendment Act 2007 (Austl.).

173. CAL. Prob. CODE $\S 5040$ (b) (2) (West 2017).

174. Hirsch, supra note 1 , at 646 .

175. In Mearns, the decedent had canceled one insurance policy that named his ex-wife as beneficiary, but told his insurance agent he wanted to keep a second policy with his ex-wife as the named beneficiary. The agent did not have decedent re-designate the now ex-wife as beneficiary, but the court held that Washington created a "bright-line rule" so that the presumption applied, regardless of evidence of the decedent's intent. Mearns v. Scharbach, 12 P.3d 1048, $105^{2-53}$ (Wash. Ct. App. 2000). 
judicial discretion and would also provide some controls for judicial efficiency against frivolous filings. ${ }^{176}$

This new evidentiary standard might embroil courts in more estate litigation, and, as a result, legislatures may be reluctant to adopt this more contextual analysis because of the potential for declining efficiency and confusion throughout the probate process. ${ }^{177}$ On the other hand, it might prompt insurance companies to send out more frequent notices requesting that holders update the list of beneficiaries. ${ }^{178}$ Yet by respecting intent, this new evidentiary standard would be in accord with the more general movement away from formality.

\section{b. Guardianship of a Child}

States might consider the approach of Scotland, in which the appointment of a former spouse or civil partner as a guardian to minor children is not subject to revocation. ${ }^{179}$ In most situations, this will be irrelevant: a surviving parent becomes the sole legal guardian if the other parent has died, ${ }^{180}$ and thus a revocation would have no impact if the exspouse were also the legal parent. However, if the decedent had been widowed and an ex-spouse had not adopted the decedent's children, the decedent might prefer an ex-stepparent to a third party.

\section{iii. $\quad$ Time Limit}

One more option is to retain the current presumption, but to limit its application (as is true in South Africa ${ }^{181}$ ), so that it is effective only for a certain amount of time after the divorce has been finalized. This allows the decedent time to change the beneficiary designations, with the assumption that if they are not changed, then the decedent's intent was to continue to benefit the ex-spouse. This presumption of lack of revocation after the time period could also be rebutted by the factors suggested above, or by clear and convincing evidence.

176. For further discussion of the use of judicial discretion with a clear and convincing standard, see generally Jane B. Baron, Irresolute Testators, Clear and Convincing Wills Law, 73 WASH. \& LEE L. REV. 3 (2016). Susan Gary notes: "Discretion may make effectuating the decedent's intention more likely. Discretion avoids trying to pin down every possible variation ... a court can address the needs of survivors, deny inheritance to those who mistreated the decedent, and provide some amount for those who aided the decedent." Gary, supra note 63 , at 812 .

177. See Boni-Saenz, supra note 38 , at 44 (making a similar observation regarding "more factintensive inquiries [that] raise the specter that more judicial resources will be consumed in carrying them out").

178. For other strategies, see Sterk \& Leslie, supra note 5, at 213-19.

179. See Beirne, supra note 144; Davy, supra note 144 .

180. E.g., Conn. Gen. Stat. Ann. § 45a-6o6 (West 2017); R.I. Gen. Laws Ann. $\$ 33-5-4$ (West 2017); TENN. CODE ANN. § 34-1-102 (c) (West 2017).

181. See Hirsch, supra note 1 , at 642 n.1 46 . 


\section{B. Statutory Changes OUtSide of PRobate LaW}

Even if states do not amend their existing revocation-upon-divorce statutes, they might be willing to require family law courts to include advice on divorce filing forms, ${ }^{182}$ or, they might want to establish standardized forms for all contracts relating to nonprobate assets when residents designate beneficiaries. The forms, which could either be recommended or mandatory, would explain the default rules, require the accountholder to signal understanding, and then allow for alternative designations. ${ }^{183}$ Other suggestions include adding reminders about beneficiary designations on annual statements or requiring account custodians to contact the accountholder periodically to request updates. ${ }^{184}$

\section{The Relationship Axis}

Turning to the second axis, the relationships to which the presumption would apply, the UPC has steadfastly focused on marital relationships, rather than choosing to broaden provisions concerning the elective share, for example, to include civil unions or domestic partners. ${ }^{18_{5}}$ Conversely, other countries have not, limited their "intimate partner"-based provisions to married couples. Given the high rate of nonmarital partnerships in the United States, it is useful to consider expanding the presumption beyond marriage. If the presumption is based on a belief that ex-partners deserve a clean break, then this presumption should apply, regardless of marriage. Arguably, it should apply even more stringently to nonmarital partners; as June Carbone and I have argued, marriage signals a commitment to sharing, while nonmarriage does not. ${ }^{186}$

Nevertheless, even if the presumption remains in its current form, then it might also be useful to extend it to legal separations or the filing of a divorce

182. See Naomi Cahn \& Amy Ziettlow, "Making Things Fair": An Empirical Study of How People Approach the Wealth Transmission System, 22 ELDER L.J. 325, 366 (2015). Reid Weisbord has made a comparable suggestion to ensure broader estate planning: state income tax returns might include "an optional schedule called a "Testamentary Schedule-Last Will and Testament" to ensure broader planning. See Reid Kress Weisbord, Wills for Everyone: Helping Individuals Opt Out of Intestacy, 53 B.C. L. REV. 877, 920 (2012).

183. This is adapted from Accidental Inheritance, see Sterk \& Leslie, supra note 5, at 220-2 1.

184. On the first suggestion, see Pension Rights CTR. \& NAT'L Women's LaW Ctr., COMMENTS TO ERISA ADVISORY COUNCIL 5 (2012), http://www.pensionrights.org/sites/ default/files/docs/120824_nwlc_and_prc_comments_for_erisa_advisory_counsel_hearing_on_ beneficiaries.pdf; on the second, see Sterk \& Leslie, supra note 5 , at 224-25.

185. See Danaya C. Wright \& Beth Sterner, Honoring Probable Intent in Intestacy: An Empirical Assessment of the Default Rules and the Modern Family, 42 ACTEC L.J. 341, 371 (2017) ("[S]izeable gaps still exist for those in non-traditional family relationships with the decedent. For example, the UPC does not provide an intestate share for unmarried, committed partners of the decedent or for non-genetic children who have not been adopted by the decedent, beyond the last-resort share for stepchildren." (footnote omitted)).

186. June Carbone \& Naomi Cahn, Nonmarriage, 76 MD. L. REV. 55, 99-102 (2016). 
petition. On the other hand, a divorce petition does not necessarily lead to divorce, so this may be a premature application of the presumption. ${ }^{187}$

Overall, expanding the presumption (in whatever form it takes) would presumably result in courts undertaking more fact-finding, adding more work to already crowded dockets. At the same time, most probate cases are uncontested, ${ }^{188}$ so it is unclear how much of a burden this expansion would cause. And the result of any additional fact-finding should more closely mirror the decedent's intent.

\section{Estate Planners Beware}

Family law and estate planning should come together in this context. Therefore, family law practitioners should advise their clients who file for divorce to change all designations in probate and nonprobate assets in favor of an ex-spouse and the ex's family members if that is the client's intent. The laws on changing beneficiary designations can be confusing, ${ }^{189}$ so it behooves lawyers practicing in both family law and estate planning to be aware of these complexities.

While family lawyers typically see clients at the time of dissolution, estate planners may be more likely to see clients in the midst of a harmonious marriage; they should nonetheless confirm with their clients what should happen in the case of divorce and draft documents accordingly. ${ }^{19}$ Of course, just as people are reluctant to plan for death, they are reluctant to plan for divorce; nonetheless, coherent estate planning involves planning for both. Designating beneficiaries for nonprobate assets may, however, be "less likely to produce death anxiety than the execution of a will." ${ }^{191}$

The lawyer might include a clause at the beginning of the will that clarifies the status of all bequests to a spouse and the spouse's family members in the case of a divorce, or the will might address each bequest individually. For example, one way that a practitioner might remedy this situation would

187. Cf. Hall v. Kalfayan, 118 Cal. Rptr. 3d 629, 635 (Cal. Ct. App. 2010) (discussing a case in which an unsigned will was not a basis for malpractice, as intent might have changed, resulting in non-execution). A court might presume that intent might change before a final result in a divorce petition, just as it has regarding the execution of wills. See id. ("Although a potential testator may also change his or her mind after a will is signed, we perceive significantly stronger support for an inference of commitment in a signature on testamentary documents than in a preliminary direction to prepare such documents for signature.").

188. See David Horton, In Partial Defense of Probate: Evidence from Alameda County, California, 103 GEO. L.J. 605, $629(2015)$ (“[M]y results are eye-popping: of the 668 estates, eighty-three (12\%) involved litigation.”).

189. Leslie \& Sterk, supra note 35, at 84 (describing beneficiary designations laws as "unwieldy and complex").

19o. See also Sterk \& Leslie, supra note 5, at 211 (suggesting how lawyers can help clients designate beneficiaries "in a way that fits into the testator's estate plan").

191. Mark Glover, The Solemn Moment: Expanding Therapeutic Jurisprudence Throughout Estate Planning, 3 Suffolk U. L. ReV. Online 19, 22 (2015). 
be to state something like "[i]f Spouse is no longer married to me, does not survive me, or cannot otherwise take under this will provision, I leave this property to X." ${ }^{192}$ or "if I am no longer married to Spouse, then all bequests to any relative of Spouse who is not also related to me apart from my relationship to Spouse shall fall into the residue; or if I am no longer living with Domestic Partner, then I leave this property to Y." ${ }^{193}$

\section{CONCLUSION}

Since its inclusion in the UPC in 1969, revocation upon divorce provisions have expanded in coverage. Yet, there is little empirical evidence to support their breadth, and changing norms in family law suggest the need to reconsider the presumptions and the breadth of its application in estates law. By exploring potential reasons for, and approaches to, changing the presumption, this Article contributes to the ongoing conversations about the relationship between decedents' intent, formality, and function in trusts and estates law.

192. Ben Schenker, Estate Planning Considerations in Divorce, 27 PrAC. TAX L. 5, 6 (2012); see Gerry W. Beyer, Effect of Divorce on a Client's Estate Plan, EST. Plan. DEv. FOR TEX. Profs. (2013) https://papers.ssrn.com/sol3/papers.cfm?abstract_id=2364823.

193. As Susan Gary noted, this language might be problematic if the decedent had moved to assisted living. See Conversation with Susan Gary (July 16, 2017) (on file with author). 